\title{
The Impact of COVID 19 on the Ethiopian Private Banking System
}

\author{
Tesfaye Boru Lelissa (PHD)
}

\begin{abstract}
To explore the impacts of the COVID-19 pandemic on Ethiopia's Private Banking System and inform interventions and policy responses, the study employed the input-output framework. It has used ten years historical data from 2010 to 2019 of the aggregate private commercial banks in order to explore trends and examine the effect of pandemic on the past critical success factors. The result shows that the pandemic has effect on both balance sheet and income statement of banks. The effect is shadowed during the current year due to good performance record all through pre COVID period. Nevertheless, it won't take much time to feel the effect of the pandemic in the private banking system as well. Therefore, the notion of considering banks less vulnerable to the crisis should be swotted. The study identified immediate liquidity need of around Birr 17 billion to private banks so that they can comfortably meet the NBE's liquidity requirement. This in fact will be challenged by less resource mobilization and reduced loan collection of Birr 10 billion per quarter. Early measures to improve the liquidity (infusing injection), capital position (setting dividend payout limit), asset quality (setting minimum provision level), earning (avoiding price pressure) and cost (controlling exchange losses) profile of banks will have paramount importance for sustainable soundness of the private banking system. In addition, the shock absorbing capability of each bank in the sector should be separately looked at for an effective remedial action. The banking business after Covid-19 shall be intensified with new sources of growth: advisory services, e-commerce, digitalization, e-banking services etc. Online and digitalization will be the way forward. Comprehensive reform and finance sector restructuring programs should be thought of in order to accommodate such changes and speed up the recovery process.
\end{abstract}

Keywords: COVID19, Private bank, Ethiopia

DOI: $10.7176 / \mathrm{EJBM} / 12-16-06$

Publication date:June 30th 2020

\section{Introduction}

Ethiopia has recorded strong economic performance over the preceding years, as reflected by the average real GDP growth rate of about $10 \%$ per annum. The growth was expected to sustain at least for the short term, provided that the favorable conditions continue to support it. Nevertheless, recent reports from both local and international institutions reveals that the past growth remained an unlikely situation due to the pandemic affecting several segments of the economy. As per the recent country report of the IMF economy growth will significantly diminish (IMF Report,2020). With regard to the banking sector, the report identified two critical effects of the pandemic are underscored: deterioration of asset quality and chronic liquidity problems.

Thanks to the regulatory protection, the well-functioning economy and the highest bank to population scenarios that sustained for more than two decades, the sector has been enjoying lucrative banking market that easily translated to profitability and earnings to its shareholders. However, similar to other business undertakings and economy wide scenario, the sector has a higher chance to be affected by the COVID 19 unless timely remedial measures are in-placed. This is because banking by nature is a fragile undertaking which is likely to be affected by the performance of the economy as well as the wellbeing of other sectors. In addition, the aforesaid two factors (asset quality and liquidity problems), being critical to determine profitability have also consequential effect on the sustainability of the banking business. In fact, pressing the performance of the banking sector will not be limited to the two factors but goes to the extent of disrupting all channels of the banking income sources.

There seems also a long stayed alleged understanding among the academics and policy makers (including regulator) that the banking sector is at a better stand than other business in curbing uncertainties and shocks. However, the author argues that it won't take much time to observe the notable pressure of the pandemic on the performance and soundness of the private banking system. Early preventive measures are a must than an option and safeguarding the sector will have paramount importance to the well-functioning of the economy and other sectors linked to the financial system.

The study tries to explore the impact of the pandemic on the core business of the private banking system and its implication from balance sheet and profit and loss perspectives.

\section{Input-output Framework (Ethiopian banks Business Model)}

The Money and banking Proclamation No. 83/1994 identify banking business as:

.... an operation that involves such activities like receiving funds, discounting and negotiating of promissory notes, drafts, bills of exchange and other evidence of debt; receiving deposits of money and commercial paper, lending money, and buying and selling of gold and silver bullion and foreign exchange. 
Even if the list in the proclamation is exhaustive, from the balance sheet and income statements of banks it can be inferred that the main stay of banks largely relied on the intermediation activities (NBE report, 2018/19). A bank is usually defined as an institution whose current operations consist in granting loans and receiving deposits from the public (Mishkin, 2001). Therefore, as core to their functions, banks need to mobilize deposits (in local and foreign currency) from the public so that they can lend the deposit to borrowers and foreign currency users and earn income in the process. The need for more liquidity is associated with the high leverage position following the very limited capital base of banks as compared to their asset holdings. For instance, the capital to asset ratio for banks in Ethiopia in year 2019 is 19\% reflecting that a great part of banks' activity is financed through deposit collection.

From the income structure of banks, it appears that the current trend in banking activities seem altered towards pursuing a mix of fee-generating activities along with the intermediation business. That is, instead of just accepting deposits and making loans; they receive good sum of earning from fee-based activities like foreign operations and off-balance sheet activities. Literature also supports that non-interest income is among the most rapidly growing sources of revenue for deposit accepting institutions (Rose and Hudgins, 2008). A similar trend has been noted in the Ethiopian banking situation where income from non-interest sources is revealing growing trend overtime. Individual banks assessment also shows that there are some banks whose fee income has constituted almost half of the total earnings. Nachane and Ghosh (2007) remarked that the dynamism in the banking sector has urged banks to be innovative in their operations. This innovation process has contributed for wider expansion in the offbalance sheet activities which are contributing for the expansion in fee income. This may, however, have effect on increasing overall risk of banks by exposing them to high income volatility. In addition, literature suggested that banks with relatively high non-interest

earning assets are less profitable (Demirgiic-Kunt and Huizinga, 1999). Despite such argument on the risk associated with holding high share of non-interest income, the significant share of fee income justifies the need to incorporate them in the analysis of bank performance. More specifically, if performance is rated based on profitability measure, excluding fee-based variables will lead to bias. For instance, Rogers (1998) explained that the exclusion of nontraditional activities in the estimation of bank performance and efficiency actually understates it.

The other scenario which differentiates banks from other businesses is that of the existence of risk factors. This is because the capital base of a bank is smaller relative to the asset base and liability it holds. In terms of the risk types, Allen and Cartelli (2008) identified two major risk types which are associated with the core activities of banks: default and liquidity risks. Thus, existence of both liquidity and default risk for a bank differentiates it from an ordinary firm and the impact of such risk factors on performance should deserve consideration.

In this study consideration for both intermediation and key fee generating activities (like foreign banking operation) is considered in an attempt to test the impact of COVID on performance. In addition, the framework incorporates major risk components (like liquidity and default risk) in order to test their effect on bank performance.

\section{Methodology}

Methodologically, the study uses descriptive approach to outline the effect of COVID19 on the key performance indicators of the banking system. It has implemented the intermediation approach of the input-output method to select the key variables to be observed over time. The resource mobilization, resource allocation, efficiency, revenue and cost variables are carefully selected to examine their sensitivities to the shocks.

As per the intermediation approach ${ }^{1}$, banks are considered as primarily intermediating funds between savers and investors; they are intermediates of financial services rather than producing loan and deposits account services. Since service flow are not usually available, the flows are typically assumed to be proportional to the stock of financial value in the accounts such as the number of dollars of loans, deposits (Berger and Humphery, 1991). Here, input of funds and their interest cost should be included in the analysis since funds are the main 'raw material' which is transformed in the financial intermediation process. This means, banks give intermediation services through the collection of deposits and other liabilities and the transfer of these funds to interest earning assets (Sealey and Hendly, 1997 cited in Isik and Hassen, 2002). Deposits are included as third input along with capital and labor. As a result, Operating costs, as well as interest costs, are taken into account in the production process. The study applies the intermediation approach which is appropriate for evaluating the entire banks through

\footnotetext{
${ }^{1}$ The other approach is call production approach. As per this approach, banks are thought as primarily producing services for account holders. They are considered as firms which employ capital and labor to produce different types of deposit and loan accounts. They perform transactions and process documents for customers, such as loan application, credit reports and payment instruments. Under this approach, outputs are measured by the number of deposit and loan accounts or number of transactions performed on each type of product, while total costs are the operating costs used to produce these products. Banks are viewed as producers of two types of services: deposits of funds and users of funds. The production approach may be somewhat better for evaluating the efficiencies of branches of banks because branches primarily process customer documents for the institution as a whole and branch manager typically have little influence over bank funding and investment decisions.
} 
incorporating inputs from core operation of banks. The approach is inclusive of interest expenses which often accounts for one half to two third of total cost. Besides, the intermediation approach is superior for evaluating the revenue and cost impact of the banks since minimization of total costs, not just production costs, is needed to maximize profits.

Fig. 1: The Banking Model of the Private Banking System

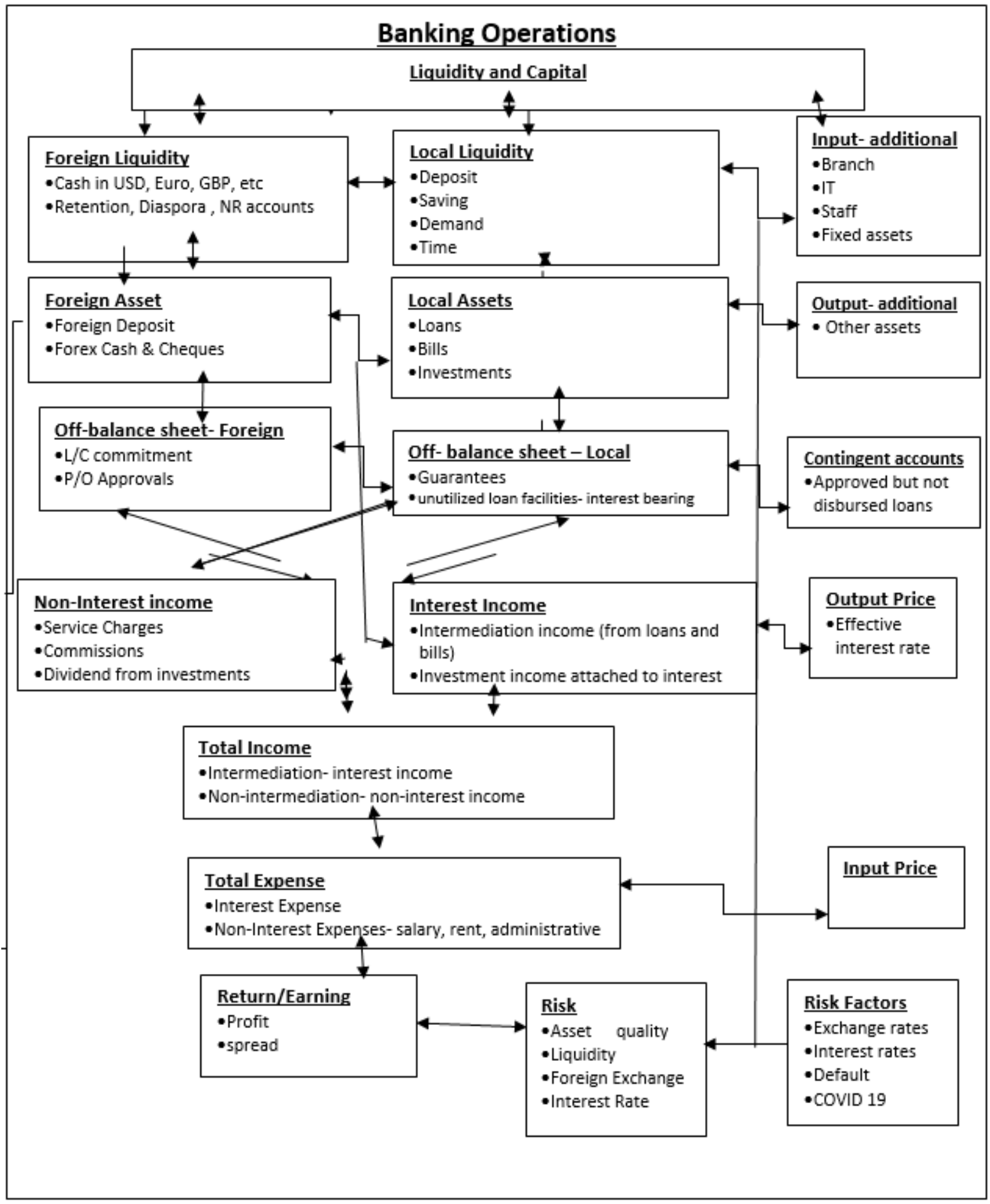

\section{Author's Framework}

\section{Data and Data sources}

The study uses firm level (mainly private commercial banks) as well as aggregate data of the private banking sector and the economy. The major data sources are the various annual and quarterly publications and financial accounts of NBE and commercial banks. Basically, the coverage is for ten years from 2010-19 inclusive and consisting of 
all 16 private commercial banks in Ethiopia.

\section{Summary of Input/Output/prices and effective Rate- Variable Descriptions}

$\begin{array}{lll}\text { Inputs } & \text { Prices } & \text { Price/input } \\ \text { Deposit } & \text { Interest expenses } & \text { Cost of fund } \\ \text { Branch } & \text { Staff expenses and rent } & \text { Branch running costs } \\ \text { FCY } & \text { Depreciation, amortization } & \text { Fixed asset depletion rate } \\ \text { Capital } & & \\ \text { Outputs } & \text { Prices } & \text { Price/output } \\ \text { Loans and advances } & \text { Interest income } & \text { Effective interest rate } \\ \text { Other Earning assets } & \text { Non-interest income } & \text { Earning rate of non-interest income sources }\end{array}$

3. Analysis

3.1. Impact on Resource Mobilization (Deposit)

The expansion on the asset base of private banks was rapid for the past ten years with an average growth rate of $27 \%$ per annum, which is an exact replica of the expansion rate in the deposit base $27.9 \%$ and lower from the growth rate of the credit portfolio $32 \%$. Such notable growth of resource mobilization is as a result of the rise in per capital income, expansion in branch network and growing saving habit and bank usage (NBE report 2018/19). Worth to note, the strong deposit growth in the past years was facing a challenge during the recent quarters of this fiscal year enforcing the industry to witness severe liquidity problem. Recent studies show that the liquid assets to deposit ratio of banks persistently was below the liquidity requirement. The slowdown in deposit growth is even more pronounced if one looks only at trends in checking deposits (business savings), which grew at a rate of just $23 \%$ in the most recent fiscal years as compared to $32 \%$ and $31 \%$ of the previous two years. More specifically, industry wide share of the demand deposit is now closer to $24 \%$ as compared to above $50 \%$ a decade ago. Despite the aforesaid challenges, the COVID effect on local deposit mobilization could have substantial effect considering the sources of deposits and liquidity bases of Banks. As outlined above, the pandemic could have impact on the past reasons for the momentous growth of the resources bases of banks i.e. per capital income, growth in branch network and saving habit and bank usage. If we look at each factor:

a. Per capita income-The Covid-19 pandemic affects all major world economies, predicting a major world economic crisis in 2020. Ethiopia will not be an exception as several adverse trends would seem to dominate the near-term economic outlook. For instance, recently published reports show that even with limited virus spread scenario, the economic outlook will be far less than the planned with the effect being pronounced on few segments of the economy like export, hospitality, manufacturing and banks ( Cepheus Research , 2020, Geda,2020, EEA,2020, IMF, 2020). More specifically, the recent country report of the IMF remarked that Ethiopia is facing a pronounced economic slowdown and an urgent balance of payments need owing to the COVID-19 pandemic. The shock is expected to significantly reduce growth this fiscal year and next, with the revised growth projections from 6.2 and 6.1 percent to 3.2 and 3.7 percent in 2019/20 and 2020/21, respectively. Numerically, a study shows that under three different scenarios: best, average and worst scenario, the annual GDP level is to reduce the projected GDP by 114 billion, 227 billion Birr. and Birr 341 billion (Geda,2020). Official report from the government offices also admit that GDP growth could reach to $5 \%$ from the original plan of a $9 \%$ growth rate accepting the average scenario of Birr 227billion GDP reduction. Sector wise, during these hard moments it can be seen that all those variables included in calculation of GDP are concerned: decrease of consumption, investment, government expenditure, export and import. In such conditions, GDP will necessarily decrease as consequence of decline of its determinants.

Ethiopia with a population of more than 110million remains one of the poorest countries in the world. Previous year records elucidated the decline in the number of people under poverty line but still there is a large segment of the population ( $>25$ million) leading a miserable life under the poverty line. As stated above, economy wide scenario will remain unfavorable for the coming period putting a lot of lives under a stressful economic condition. For instance, with the average effect of a GDP decline of Birr 227 billion will draw sown the per capita income by Birr 2100. Therefore, the growth in per capital income, which has been a good reason for local resource mobilization will be affected pointedly. Theoretically, as income rises, marginal propensity to consume falls while marginal propensity to save increases. The current epidemic has brought a decline in both side of equations where the decline in income could affect the consumption and saving status of the people. The effect of the above equation implies a decrease in the potential growth of the GDP due to a decrease in the consumption level on the one hand and the possibility of a decrease in the saving level of the people.

b. Expansion in Branch Network - One of the notable achievements of the Ethiopian banking sector over 
the past decade was the large-scale expansion in the branch network across capital and outlying regions. More specifically, driven by the GTP II indicative targets for $25 \%$ branch expansion rate and after the NBE's requirement for banks to set aside $27 \%$ of their new loan disbursement for Bill investment, ensuring accessibility remained the strategy of Banks to mobilize large deposit from the market. The strategy appears successful for relatively long time as the trend in deposit growth was persistently positive. Nevertheless, banks prefer to hold their branch expansion rate, which was above $30 \%$ recently was reduced below $20 \%$, due to the gradual reduction in the deposit per branch as well as the increase in branch related costs such as salary payments, rent expenses. In addition, the introduction of e-banking channels are also additional factors to contain the expansion rate in branch network. The effect of pandemic obviously affects the branch expansion rate across the banking industry as:

- banks are discouraging branch level services and are heartening customers to use other non-branch channels like ATM, Mobile, via providing incentives such as revoking of fees, increasing transaction limits etc;

- Banks income generating activities are directly affected by the pandemic; hence, pursuing long term expansionary strategies might not be a preferred way of growth under crisis situation;

- The galloping inflation rate also affects branch running cost - cost for employees, rent expenses, other administrative expenses etc;

- The resource mobilization exertion, which was a good incentive to open branches across every corner, remains sluggish due to feeble economic performance as indicated above.

c. Saving Habit and Bank Usage- the domestic saving of Ethiopia is around $24.3 \%$ of the GDP, which was improving trend wise and remains better as compared to sub-Saharan average of 18.3\% (World Bank,2018). Several studies conducted in Ethiopia show a unidirectional relationship between gross domestic product (GDP) and domestic savings; that causality run from gross domestic product (GDP) to domestic savings (Samuel, and Abebe, 2015, Jember,2016, Abel,2016). Theoretically, such relationship wittiness the Keynesian point of view that savings depend upon level of output. As stated above the impact of COVID on economic growth is significant; therefore, it apparently affects the saving level in the economy.

To look at the saving habit in the banking sector, considering the deposit mix of banks might provide some insights. The stock of private banks deposit mix for most part, ensured a balanced and sustained mix of deposits that comprised above $60 \%$ savings deposits, $26 \%$ checking deposits and $12 \%$ CD deposits. Still the majority of the deposit is a contribution of individual savers, which is growing over years at better rate than other deposit types. This is in line with the NBE's justifications for the increasing awareness and saving habits of the society during the past periods. The share of checking deposits in total deposits, averaging exactly $26 \%$ over the past decade was somewhat moving downward and has registered a slower growth rate in the recent period. While higher-cost CD deposits were rarely relied upon as a financing source in the early years (5-7\%), this was rapidly increasing to just $12 \%$ of deposits. On the good front, the saving deposit has shown a tremendous growth of $27 \%$ over the past decade, keeping its share not lower than $60 \%$ from the total deposit. COVID has a direct effect on sustaining such saving culture trend as:

- Resource mobilization, which is mainly done through large scale personal contact and ensuring accessibility, will not be an easy endeavor as the pandemic limit personal contacts. Personal contacts are still the way pursued by banks in account opening and transaction processing.

- Cost saving deposit types like demand deposits which were moving on the downward trend in the past years will follow similar pattern as a lot of businesses are now in distress conditions.

- The only deposit type that can show increment at significant percentage could be the time deposit as businesses and individuals prefer to hold their investment during crisis time.

- The slow in credit granting, which is a result of low businesses and fear of default, also limits the deposit creation rate, restricting resource mobilization activities.

Regarding bank usage, the number of adults having accounts on regulated institutions in Ethiopia is at lower lever- $35 \%$ which is far lower as compared to, $82 \%$ in Kenya, $50 \%$ in Rwanda, and $43 \%$ of adults in the region (World Bank,2017). The percentage of account penetration have shown an improvement thanks to the expansion of commercial bank branches and the increasing level of awareness in the society. Mobile money accounts are still limited- only less than one percent adults reflecting the less technology adoption rate. In such regard the pandemic will have a mixed implication:

- Digitalization- which has been a neglected matter for long- gets a thoughtful attention and remains to be the innovative form of financial services in the Ethiopian financial sector. The recent move by the NBE to limit the cash withdrawal amount by individuals and businesses as well as the crafting of digital strategy are some of the indicators of such thought from the regulatory and government organs. 
- Bank branching- as stated above the pandemic negatively affects the branch and outlet expansion rates.

- Marketing and Banking Awareness-Marketing is one of the approaches undertaken by banks to mobilize resources and increase their customer base. Various approaches including social media, advertising on various channels (tv, print, audio/radio) etc were executed in order enhance bank image and create awareness about banking in the society. The usual door to door promotion and customer snatching, which was instrumental to enhance the customer base and resource mobilization, now cannot be pursued in large scale due to COVID. Campaigning and personal selling activities are limited; therefore, Banks promotion strategies are directed towards electronic and print media. The contents of such advert are usually are not related to the banking business but are focused with the intent to reposition as corporate responsible citizen and responsible bank. Even if this remains legitimate and pays off by large in the future, apparently impacts the resource mobilization endeavors and efficiency of banks.

\subsection{Impact on Foreign Currency Earning}

\subsubsection{Export}

For the past decade the Ethiopian export earning has stayed around 3 billion with annual average growth rate of more than 10 percent during GTP1 to only 6 percent during GTP2 (GTP I and GTP II). Ethiopia has taken several export policies and strategies in recent years, however, the extensive policies and measures undertaken by the country have not yet generated the envisaged form and quality of export growth. The export items are mostly related to primary agricultural and few semi-finished goods such as Oilseed and pulse, Coffee, chat, Leather and Leather products, Live Animals, Textile, Gold and Horticulture. Trend wise analysis indicates that the export sector of the country appears to be weak and in the most of the year the growth rates the remaining years is barely positive. The weak performance of the export earning is generally attributed to the decline in volume of major export products and deterioration in international price of major commodities like coffee and gold. The pandemic exacerbated the above trend as Ethiopia's largest trading partner, China, will by itself shown a large slowdown in both its growth rate (from near 10 percent to 6 percent) and in its import growth rate (from around 20 percent to below 10 percent). Other large markets for Ethiopia's exports (Europe and US) are also not expected to show a very dynamic growth or import trajectory for the coming years, which would suggest limited scope for Ethiopia to export to them or seek their foreign investment. The commodity price outlook for Ethiopia's top exportscoffee, gold, sesame - also does not seem very positive given projections by various industry experts that project prices to decline or remain largely unchanged from current levels. Most importantly, some exportable items like flower, which were main income source for some banks, are significantly affected threatening the foreign currency earning of the country and banks.

\subsubsection{Remittances}

Migration and remittances are an integral part of the world economy today. There are approximately 250 million (3\% of the world's population) international migrants as of 2015 (Migration and Remittances Factbook 2016). According to the report, the United States was the largest remittance source country, with an estimated $\$ 56$ billion in outward flows in 2014, followed by Saudi Arabia ( $\$ 37$ billion), and Russia ( $\$ 33$ billion). India was the largest remittance receiving country, with an estimated $\$ 72$ billion in 2015 , followed by China ( $\$ 64$ billion), and the Philippines ( $\$ 30$ billion). The worldwide remittance flows have increased from $\$ 602$ billion in 2015 to an estimated $\$ 714$ billion of which above $70 \%$ of total remittances believed to have been received by developing countries (The World Bank ,2019 data update).

According to world bank report ,2019,In the medium-term, the growth of remittances would continue to be restrained by high costs of remittances and stringent financial regulations like AML/CFT acts but admits that there are pressing factors (like instability, poor economy, climate change etc) encouraging migration from low income to high income economies. According to the World Bank's Remittance Prices Worldwide Database, the average cost of sending \$200 to LMICs was 6.8 percent in the second quarter of 2019, which is more than double the Sustainable Development Goal (SDG) target of 3 percent by 2030.

Concerning Ethiopia, the total stock of emigrants is estimated to be 800 thousand which is equivalent to $0.7 \%$ of the total population as of 2019. The Country's top migrant destination countries are Sudan, the United States, Israel, Djibouti, Kenya, Saudi Arabia, Canada, Germany, Italy, and Sweden. Ethiopia's remittance has been fluctuating overtimes. The recent estimate for the total official remittance to the country has reached nearly \$531 million from \$1,087 million during year 2015 though the actual remittance from both formal and informal means is by far more than the $\$ 500$ million (i.e., US $\$ 3.2$ billion per year as per the study conducted by Bendixen and Amandi (B\&A).

The two major players in the remittance business in Ethiopia are Banks and Money Transfer Operators (MTO). Currently, there are about twelve local banks which provide remittance service in collaboration with the remittance service providers. The cost of international remittance service ranges as high as $26 \%$ of the amount to be sent to 
$0.01 \%$ depending on the remittance service provider, country and amount of remittance.

The economic crisis induced by COVID-19 has a direct impact on the remittance business as:

- Lockdowns, travel bans, and social distancing and also the possible loss of employment, wages, impacts the amount of remittances from the emigrants;

- Ethiopia also witnessed several returnees of its citizens from the middle east and Asia due to fear of contagion and bad economic situation in host countries.

In a nut shell, the two crucial and persistent sources of foreign currency for banks and the country are affected by the pandemic.

\subsection{Impact on Capital Mobilization}

Capital is one of the key resources of banks which serves a buffer in times of crisis as well as source of investment for good times. In such type of perilous period, it appears important to beef up the capital base of banks so that they can able to absorb the risk emanating from worst economic and financial conditions. This scenario was a proven fact during the 2008 financial crisis where banks that were in relatively weak liquidity and capital position were much exposed to the upheaval. That is why many of the regulators like the NBE demand banks to hold a minimum capital requirement level based on the level of risk weighted assets. The NBE directives demands banks to strictly maintain a capital level exceeding or equivalent to $8 \%$ of the risk weighted assets.

Looking at the private banking sector, the gross capital to total asset ratio appear stable over the past couple years- it provides coverage of around 14\% thanks to the NBE's encouragement for banks to increase their capital level. The minimum capital requirement to establish a bank is now set around Birr 500 million and for exiting banks an indicative a 2 billion capital growth target was demarcated during the GTP II. Even if the capital to asset ratio of banks is on good front, the growth in risky assets like loans and advances was higher than the capital growth rate creating a concern in the future. Hence capital growth requirements should remain part of the regulatory precautions in the forthcoming. In such regard, the NBE should set enforcement measures to keep part of this and subsequent years profit to serve the buildup of the capital base of banks. In addition to serving as cushion in times of turbulence, strong capital also keeps banks liquidity standing resilient. It remains important to banking business expansion through increasing the capacity of banks to achieve large credit extension for a single borrower and boosting their capacity to hold an increased foreign currency holding. This will be very relevant to the Ethiopian banking industry where the lending decision to single borrower, $25 \%$ of capital (Directives SBB/53/12) and foreign currency positions, $15 \%$ of capital (Directives SBB27/01) are directly attached with the capital level by regulations. Therefore, an enhanced capital level remains an important driver for banks to register a rapid balance sheet expansion, boost their earning position through directing their activity to a high growth- high earning scenario and without worrying much about liquidity shortfall.

\section{Resource Allocation}

\subsection{Loans and Advances}

Loans and advances are the major asset components that took the lion share of the balance sheet of the banking sector. The share of this asset from the total asset is progressively rising following the higher dominance of the traditional intermediation business in the Ethiopian banking sector. Growth wise as well, the loan book of the private banking system appears significant even usually exceeding the growth rate of deposit. The issuance of the bill purchase after 2011 seems to have impacted the efficiency of intermediation so that banks are utilizing every penny from their deposits to be allocated for loans and government bill purchases. Looking at important variables like the Loan to Deposit ratio witness the fact that deposit conversion in the form of loans has been strong over the periods and lending remained the core activity of banks. Intermediation business is a heated undertaking and even sometimes lending exceeding resource mobilization endeavor. The level signals the high demand for credit in the industry which eased the conversion of deposits to loans. The dependence on intermediation perhaps will not be a surprise considering the limited areas of engagement for banks due to the underdeveloped financial system and lack of other supporting markets.

Thanks to the NBE's timely move to lift the bill purchase requirement (came into effect as of November 20, 2019), there shall be considerable resource to ensure a reliable liquidity position. The NBE already have paid Birr 15 billion (a year and two months) bill to be matured within the coming one year and two months from March 2019. Therefore, expecting additional payment for bills demands another strong request from the banks and/or for apparent liquidity crunch. In fact, the NBE has provided alternative options to banks liquidity via allowing to borrow from the central bank for a month with an interest rate of 13\%. Even if this remains to be a strong measure to ensure the tender of last resort role of the central bank, the fund could not be allocated for credit extension. Therefore, besides the slowdown in economic performance that triggers for limited expansion in loan demand and lending appetite of private banks, the weak resource mobilization possibility restricts the future expansion of the loan book of private banks. So as to curb resource side related problems placing banks in reliable liquidity status should remain a priority task of the NBE. 


\subsection{Loan Collection and Disbursement}

Despite the difference in the modality and effort of collecting loans, there is considerable amount of loan collection from the stock of the banks' credit portfolio. The quarter and annual loan collection amount for the private banking system stood at Birr 24 billion and Birr 100 billion, respectively- that is almost $10 \%$ and $40 \%$ of the total loan portfolio, respectively. In order to maintain or exceed the current stock of loan portfolio, banks are expected to disburse significant amount of fresh loans on continuous basis. Otherwise, credit growth on the one hand and credit quality on the other will be compromised both impacting the earning base of banks. In other words, the influence of the pandemic is observed in both sides of credit activities- disbursement and collection whose effect on the credit portfolio and quality depends on the direction and magnitude of the two activities is as shown in the below matrix.

Table1: Disbursement and Collection Matrix

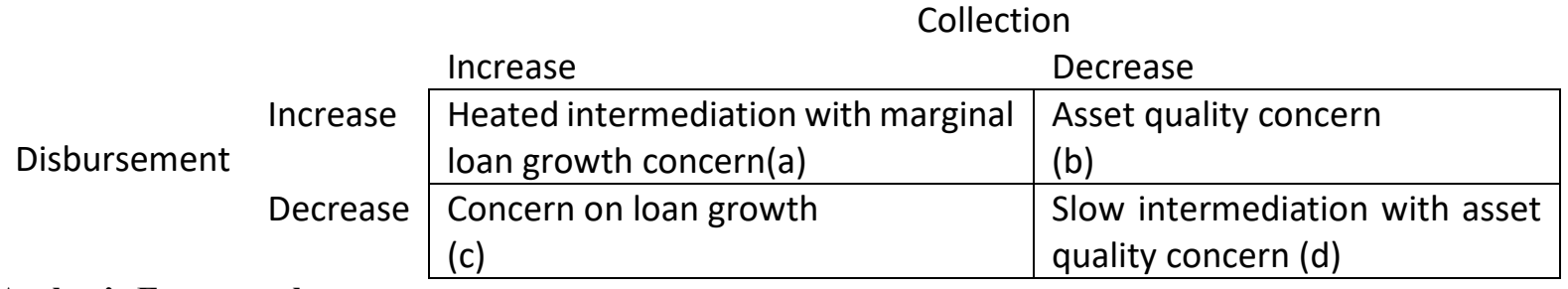

\section{Author's Framework}

From the above matrix, it is easy to observe that the consequential effect of COVID 19 on disbursement and collection activities resembles the situation of quadrant ' $d$ ' where the sluggish in loan disbursement and collection activities result in slow intermediation to ensure loan growth and bring asset quality related concerns. With the other more probable scenario of quadrant ' $b$ ', banks can ensure loan growth through extending fresh loan disbursement but asset quality related problems remain at the forefront of the credit management system of banks. In both scenarios, the impact on the earning of banks is negative with the magnitude dependent on the level of impact of the pandemic. Even if the NBE has taken provisional measure to address asset quality problems through relaxing directives, it cannot address the asset quality concern arising from bad collection of loans and advances.

A further exploration on the matter through observing the sector distribution of the loan portfolio of banks shows that there are several business sectors that are demanding for support in loan restructurings and waivers of payments. The Sector wide distribution of the loan portfolio for private banks witness dominance of trade related sectors (DTS, Export and import) together accounting $56 \%$ of the private banking loan book. This is unlike to the public banks where the industry sector is taking the lead and trade related sectors have a reduced share. Taking into account the degree of vulnerability of various sectors, it is estimated that the private banking system might not collect around Birr 40 billion and Birr 10 billion per annuum and per quarter, respectively from its loan portfolio stock due to aggressive rescheduling practices (see annex 5).

\subsection{Asset Quality}

One of the critical success factors for better bank performance is its ability to manage the risk emanating from defaults. A bank balance sheet is mostly a composite of various asset elements such as cash, foreign deposits, reserves at the NBE, loans, investments, fixed assets etc. However, the loan portfolio remains to have the dominant share of the asset especially for banks that highly rely on the intermediation business for their earnings. Therefore, keeping the quality of such asset is witnessed in many studies to affect performances. For instance, Dang (2011) claims that delinquent loans are the highest risk components whose poor handling can lead to substantial losses. Similarly, Liu and Wilson (2010) finds that problem in credit quality reduces the profitability measures, the ROA and ROE.

In terms of maintaining asset quality records through controlling of non-performing assets, the private banking system was in satisfactory situation. For instance, the ratio of provision to total loans shows that banks on average were holding a provision level of around $4 \%$ of their outstanding loans. This is a bit higher than the provision required for outstanding loans had all loans been in pass status and is closer to the provision required for loans under special mention status (3\%) as per the directives of the NBE (SBB 43/2008). Therefore, based on such comparability, the level of industry wide problem asset stock does not seem significant. Despite variation across each banks in the sector, the overall record follow the regulator which has set a directives/circulator for banks to maintain their non-performing loans to $5 \%$ of their outstanding loans which later revised even to a reduced level ,3\% as per a circular issued in relation to meeting the Growth and Transformation Plan of the country (BSD09/2015). In other words, prior to COVID 19 asset quality problems in the private banking system have no systemic nature and are related to the management of individual banks. Currently, however, an apparent pressure of default due to systemic problems are materialized and are being wisely dealt by the NBE via relaxing of asset classification and provisioning directives. At least for the short-term the directives allow banks and borrowers to get a breathing space till situations get improved. Under normal circumstances, in handling problem loans commercial banks have 
two broad choices, workout or liquidation - and, within each choice, there are various alternatives ${ }^{1}$. The NBE's direction favors banks to pursue the workout strategies and to hold the other option unutilized for the time being. The typical workout strategies that banks need to seriously pursue in order to avoid long staying defaults include:

- $\quad$ Reducing the credit risk exposure of a bank; for example, by having the borrower provide additional capital, funds, collateral, or guarantees;

- Working with the borrower to assess problems and find solutions to increase loan service and repayment capacity, such as the provision of advice, the development of a program to reduce operating costs and/or increase earnings, the selling of assets, design of a debt restructuring program, or changed loan terms;

- Arranging for a borrower to be bought or taken over by a more creditworthy party, or arranging for some form of joint-venture partnership;

Therefore, the measures banks should take should be comprehensive enough not to shelve problems and to enable resolve borrowers' debt repayment obligations.

\subsection{Foreign Currency Allocation for Import-}

Another resource allocation role of the banks relates to dispersal of the mobilized foreign currency resources to needy sectors based on the NBE's requirements. Banks usually allocate the residual foreign currency- after surrender to the NBE, shipping payments and other commitments (liabilities in retention account and diaspora/NR accounts etc) depending on their foreign currency earning levels. Therefore, the amount of import allocation is a direct derivation of the amount of foreign currency earning from various sources. As discussed in the previous sections, foreign currency mobilization will be significantly affected as the earning from export, remittance and other sources is vulnerable to the effect of the pandemic. This will apparently reduce the amount of import approval and hence, the income generated from deploying foreign exchange resources (service fees plus revaluation gains). The impact is proportional to the magnitude and direction of reduction in foreign currency earnings (it is estimated that foreign currency earning of banks could be reduced above $30 \%$ for the coming three months- which is similarly preceded by import reduction by same amount in the private banking system). As it will be discussed in the next section, following the pandemic banks are providing priority to the COVID 19 related imports and are also reducing their fees on import and letter of credit extensions. This not only impacts the fee and commission of banks but could also reduce the amount of foreign currency to be allocated to other economic sectors. The directives outlining the manner of allocation of the foreign currency resources is still operational. Nevertheless, it has some restrictive clauses for banks to support the forex demand of their own clients as the directives enforces allocation to be done on first come and first basis. As banks are busy about supporting their customers via restructuring debt and resuming their businesses, the directives need to be reviewed by providing right to banks to allocate a portion of their earnings to support vulnerable customer groups. This is besides the lifting of the directive related to the application of the $30 \%$ surrender requirement on export earnings as will be discussed in the next section.

\section{Liquidity}

The liquidity status of a bank indicates the bank's position to meet its obligations in a timely and effective manner. The need for more liquidity is associated with the high leverage position following the very limited capital base of banks as compared to their asset holdings. For instance, the capital to asset ratio for banks in Ethiopia is around $14 \%$ reflecting that a great part of banks' activity is financed through deposit collection. Regulators in most countries set the minimum required level of liquidity holding of banks. A similar trend is witness in Ethiopia where the NBE set the liquid asset to deposit ratio which is expected not to fall below $15 \%$ of the Bank's net current liability of which around $5 \%$ is expected to be held in the form of primary reserve assets, cash and assets easily convertible to cash (see directive no SBB 55/2013).

In most of the years of the past decade, the liquid asset to deposit ratio, a commonly used measure of liquidity level by the NBE, shows that during the periods considered, banks are operating at a reliable level of liquidity. Despite occasional adjustment in the regulatory requirement, the level of liquidity holdings appears to exceed the standards of the NBE (15\%). Nevertheless, in the recent year and before COVID 19, the private banking system has already reached the maximum limit on loanable funds (given 5 percent mandatory reserve requirement) and was a tough period to keep the NBE's requirement. Additional lending going forward will thus be more closely dependent on securing additional increases in deposits and will not be easily achieved as in the past year since there are now much less 'idle' deposits.

In addition, the banks' loan-to-deposit ratio that never exceeded 56 percent over the past decade has now even surpassed the $70 \%$ threshold indicative limit used during the old days (before NBE bills). In other words, the Banks

\footnotetext{
${ }^{1}$ As the term implies, a workout is a process of working with the borrower until the loan is repaid, in part or in full, and not relying on legal means to enforce collection. Liquidation is forcing borrowers to comply with the terms of the loan contract and employing and exhausting every legal means to accomplish this objective.
} 
are not yet in a comfortable liquidity position reflecting the need for further support from the NBE. Besides, slow in resource mobilization, the aggressive rescheduling on loans (intended to support borrowers by providing relaxed terms) alters the maturity profile of the banks' assets and liabilities via directing the loan portfolio towards medium and long term. Without a change in the deposit structure, the maturity mismatch between assets and liabilities will be a good reason to create liquidity stress in the near future. The study estimates additional liquidity requirement for the private sector amounting Burr 17 billion is required to keep the $70 \%$ threshold or meet the NBE's $15 \%$ liquidity requirement by private banks. This is excluding the Birr 10 billion liquidity gap from delayed credit collection.

Table 2: immediate liquidity requirement -in millions of Birr

\section{Loan Balance}

Deposit

Deposit level required to keep the loan to deposit ratio at $70 \%$
$365,009.6$

Required new funding

This can be derived from either paying NBE bills of the private commercial banks and/or reducing the primary reserve balance at the NBE from $5 \%$ to $3 \%$ (which covers around 7 billion) and the capital reserve (setting a cap for dividend pay-out ratio). In addition, banks bear the burden of liquidity stress arising from loan collections which is Birr 10 billion within a quarter via mobilizing resources form active sectors and limiting credit expansions.

\section{Off-balance sheet route}

The private banks are also extending supports via the off-balance sheet route. There has been an increase in the growth of off-balance sheet exposure in recent years and the role of private sector banks is improving on this score. Most of the balance sheet activities of Ethiopian banks are related to commitments for different types of guarantees (custom, bid bond, performance, advance suppliers etc), letter of credit commitments and approved but not disbursed loans including unutilized credit facilities having a revolving nature (like Overdraft, pre-shipment and merchandise limit).

Concerning guarantees, the major source of different forms of guarantees is the construction sector. The country's construction and real estate sector contribution to GDP has been $18 \%$ on average for the past five years. The sector has been on an increasing and was one of the contributors for the notable GDP growth registered in the past. In addition, the construction sector is also the largest employer in the country. Nevertheless, during the past two years, the sector growth was at decreasing rate due to challenges facing the industry, from mounting debt to difficulty in sourcing the right materials. The construction sector is not a standalone industry but targets set in various sectors will have significant impact on the Construction Sector including roads, dams, health centers, schools, housing development, irrigation \& potable water supply, etc. The impact of the pandemic on most of the aforesaid sectors doesn't look positive; hence, it will have similar effect on the construction sector. This will reduce the exposure of banks on new guarantee sources. In order to attract the customers, the banks have been reasonably changing the commission rates but the scarcity of could drive the guarantee fees to marginal level. Despite such factors, with regard to such product banks need to be supported:

- Contractors screening procedures should be tighter than the usual way during project awarding decisions;

- Project execution milestones should be seriously monitored so that claims to the banking sector shall be avoided or minimized; and

- Most importantly contractors failing to deliver their contracts shall be severely dealt with so as to avoid future contract failures and project delays.

The other sector serving a route to the off- balance sheet commitments of banks is the import sector. As discussed above, the performance of the import sector is highly dependent on the availability of foreign currency. A reduction in foreign currency inflow will have a direct impact on the on-balance sheet exposure - reduce level of import letter of credit. This will also impact the commission and service charges from the import transactions. As recommended above, export related foreign currency inflows should be exempted from surrender requirements as banks were cutting their lending rates on exports up to zero percent. The lost income from lending shall be compensated from the foreign currency related income

Credit related off balance sheet exposures (approved but not disbursed loans and unutilized facilities) might increase from the usual as businesses could not utilize their overdraft facilities as before due to slack business situations. In addition, fluctuating liquidity situations might not accommodate loan disbursements up to the approved amount. Therefore, enhancing the liquidity base and improving the business condition of vulnerable sectors will have paramount importance to ensure both on and off-balance sheet profile of private banks. 


\section{Earning}

Besides the balance sheet development, the last decade was also the time a strong performance in the earning base of private banks was witnessed. The total income of the sector grew $29 \%$ on average, of which interest and noninterest income sources growth rate was 33\% and $23 \%$, respectively. The income mix also favors the interest income source in gross, which holds $61 \%$ of the total income of banks. Like banks in other countries, the percentage share of the non-interest income sources (fees, commissions and chargers) is growing overtime to reach $39 \%$ of the total income. We can say that the sole reliance on the intermediation business (represented by the interest income)cannot guarantee profitability of the Ethiopian private banks due to the high cost of fund and increasing in the cost of doing business like salary, rent and other general administrative expenses- that grew by $32 \%$ over the decade. Therefore, it appears an obligation for banks to search for another reliable revenue source so that they can stay profitable and meet the demand of their shareholders- who are profit driven and set a high expectation on dividend payments. This was one of the top reasons that derived banks management and board to provide a strong emphasis on short-term profit rather than long-term institution building tasks. As a policy, the NBE might need not allow banks to pay the full (dividend payment ratio in Ethiopia is $100 \%$ for most banksexcept the legally required reserve all profit distributed to shareholders in the form of dividend) amount of dividend via setting the maximum dividend payout ratio for the banking sector. The earning sources of banks have multidirectional pressure from various sources which impact the sustainability of profit performance. Both the revenue and cost pressures are described herein above:

\subsection{Pressure on Interest Income and Effective Interest Rate}

Following the high share of loans in the asset portfolio of banks, the income from interest sources remains the top and reliable source of income for the private banking system. The share of gross and net interest income from the total revenue of banks stood at $61 \%$ and $36 \%$, respectively on average for the last decade. This shows the dependence of the private banking system on the traditional intermediation business to ensure profitability and beef up earning base. Lack of better investment options other than loans, absence of well-developed markets, limited service offerings like advisory services are reasons that can be cited for high concentration on the intermediation businesses. On the good front, despite the variation in grow rate level, the interest income was registering a persistent positive growth pattern as a result of the consistently expanding loan book on the one hand and due to a stable or rising effective interest rate on the other. The growth rate on the loan portfolio has already explained above but looking at the effective interest rate on loans and advances, the interest rate naturally seems variable but in practice has a fixed nature due to limited variation in interest rate applied overtimes. For instance, the effective interest rate on lending stayed closer to 13 percent for the last five years witnessing stability. In other words, unless there is a change a deposit interest rate (arising from new policy direction from the NBE), there is a rare possibility of changing (upward or downward) the interest rate applied on loans. Nevertheless, the recent pandemic alters both sides of the equation via slowing the credit growth pattern as banks won't be comfortable to lend at crisis time and /or credit demand will lower when economic performances looks not as usual. In addition, stable rice regimes are being challenged due to the subsequent request from borrowers for banks to waive or reduce price on loans. The below analysis tries to look at some of the factors:

\subsubsection{Pressure from interest rate reduction from COVID affected sectors}

The initiation to reduce the interest rate on lending was taken by banks even before the coming of pandemic and goes to the time when the NBE take a crucial step of lifting the long staying bill purchase requirement. Banks were expressing their gratitude via offering a reduced interest rate for their borrowers. In addition, after the emergence of the pandemic, there has been organized pressure/request from some groups (like hotel associations) for banks to lower/waive interest payments. The movement remained successful and almost all banks have made a revision on their interest rate policy with a positive intention of supporting the most vulnerable sectors. This however is not without a cost- for instance a three-month interest rate reduction of 7 and 3 percentage point for the three vulnerable sectors resulted in a total income loss of Birr 163 million within three months. It's easy to envision its effect on banks' income if a similar move from other vulnerable sectors was taken and/ or further price reduction is negotiated from the aforesaid sectors. For new credit extension request from identified vulnerable sectors, the response from the NBE was positive and timely as it decided to offer liquidity to banks at reduced rate so that they can lend it at 5\% interest rate. However, in order to support the banks further measures are necessary such as:

- To exempt banks from holding provision on such loans as they don't have commercial motives (at minimum banks are expect to hold $1 \%$ provision for their new credit exposures having a pass status, the provision rate increase whenever the credit status changes)

- Provide guarantee to banks in case of default so that the risk shall be transferred from banks to the government;

- Increase the interest rate to reasonable level so as to broaden the interest rate spread and to at least cover the cost of credit of banks.

- Most importantly, the liberty of banks to set lending price should not be compromised even during at this 
time as the banks' income base is very sensitive and prone to reduction to interest rate.

\subsubsection{Pressure from Accumulated Low Earning Asset- Mainly Bill Purchases}

The bill purchased by the private banking system stood more than Birr 116 billion within the eight years life of the directives- currently the figure is reduced to around 70 billion. From the outset, banks were predicting a formidable challenge arising from the directive as it affects the expansion in the loan book, reduce earning and liquidity status of banks. In addition, the exclusion of the state-owned banks was not positively considered by the private banking as it with the presumption that it contributes for unfair competition in the banking system. Thanks to the NBE, the directives is not functional now but the exposure of private banks is still large. In addition, there remains a concern on the effective interest rate - which is lower (less than the minimum interest rate required to be paid for saving and fixed time deposits (Lelissa,2014). The NBE response on such front is also appreciable considering: 1. The total lifting of bill purchase requirements 2 . An increase in the new bill prices from 3 to $5 \%$. 3. Permitting part of the bill for liquidity purpose before the maturity date (a year and wo months ahead). At this critical point the NBE should enhance its support to the private banking system via:

- $\quad$ Revisiting the price of bills (old and new) in a way at least to cover the minimum saving rate of banks plus a margin for credit related costs;

- Allowing banks to utilize a certain portion of the bill during stressful liquidity situation without charging interest;

- Most importantly, refraining from issuing similar directives associated to bank resources regardless of the causes. Some authors suggest for the government to introduce similar directives in order to collect resources from the banks. For instance, Geda(2020) recommended the NBE to introduce COVID bond in consultation with the banking community with the ultimate objective of mobilizing fund for the prevention and control of the pandemic. Nevertheless, this remains to repeat the previous history and shortcomings of the bill purchase directives of the NBE that drained a lot of resources from the banking sector that could have been used for the expansion and development of the banking business in Ethiopia. In addition, the past and current economic and banking environments are different to entertain measures like bill purchases. Currently, banks already have maintained a large resource base at the NBE with a very low earning rate. In addition, the liquidity profile which has been strong during the past years has already following an erratic pattern questioning reliability. The past bill purchases also limited the money creation role of banks and affected their real profitability and operational efficiency (as measured by the cost to income ratio before bill and after bill have a variation of 17 percentage point and income lost due to bill is around Birr 12 billion per year). This is the main reason, among many, for the claimed rise for the lending rate and service charges in the Ethiopia banking industry. Worth to note, the sector should be protected not only from foreign banks but from deterring policies that constrain banking growth.

\subsubsection{Long stayed pressure from export sector for preferential treatment}

It seems a long staying culture for the Ethiopian banking system to offer a lower interest rate (closer to saving interest rate) for exporters. Even at some banks the export lending rate could reach zero given the exporter fulfils certain standards- like channeling certain amount of foreign currency per annum or timely shipment/honoring of sales contracts. The total exposure of the private banking system to such kind of loans is significant- around 60 billion Birr during the past year. The logic behind such lending is simple- banks can compensate the opportunity lost from interest rate reduction through increasing their fee-based services mainly of sale of foreign currency to the importers. In addition, through accumulating their foreign currency reserves, banks gain policy profit as they were operating under predictable and stable exchange regime. The spread between the buying and selling rate of foreign currencies was also an additional source of income collected from foreign exchange services. The cumulative income from foreign currency related services is expected to adequately cover the lost interest income due to reduce interest rate lending to the export sector. After the pandemic, however, such scenario will not follow the historical norm. The decline in export earning of banks due to sluggish export performances potentially reduce the earning from foreign currency sources. Loan price increases/conversions cannot easily pursued as exporters are demanding for waivers and interest rate reduction. Therefore, the effect of the aforesaid scenario is twofold: a decrease in interest income due to waiver and interest rate reduction as well as decrease in income from international banking service due to a sunk in foreign currency inflow. In order to support banks in such front:

- As suggested elsewhere in the document, lifting the surrender requirement for export related foreign currency earnings remains appropriate;

- Lifting the exchange commission payable to the NBE on each import transactions/currency approval which is $1.5 \%$ - should be looked at in order to allow banks further reduce their service charges on import approvals.

- Banks shall also be allowed to pay local commitments (like shipping and others) through home currency.

\subsubsection{Pressure from default/asset quality}

In the previous section, the study indicated that past asset quality related problems do not have systemic causes and are related to internal credit management practices. The proxy measure provision to loan ratio shows low level 
of asset quality problem in the private banking system which is uncovered to strict regulation from the National Bank of Ethiopia as well as internal bank management. Nevertheless, the current problem is systemic and without the NBE's early measure of flexing loan classification and provisioning directives, it's apparent that banks could not manage their nonperforming asset level. This can be seen with the increasing demand from borrowers for credit renegotiation as well as the vulnerability of various business to the effect of the pandemic. The directives obviously will not be a panacea to the long-term asset quality related problems and the multidimensional effect of credit risk cannot be easily circumvented. Credit risk increases the cost of credit through affecting provision expenses, narrows intermediation margin excluding non-accrued interest from income recognition; limits the flow of funds from loan collections as a result of default and/or late payments. Therefore, even if the income pressure in the short-term might not be felt precautions with regard to:

- Limiting the general provision expense for banks portfolio shall be limited not to be less than a certain threshold (not to be less than $3 \%$ of total loans as instance);

- $\quad$ Limiting the dividend payout ratio or fully retaining the current year profit as a cushion for credit risk;

- In-placing close monitoring on restructured loans and subsequent reporting on their progress to the NBE.

\subsection{Non -Interest Income side}

Besides the traditional intermediation business, banks are offering fee-based services that assured a relatively diversified income. The share of such kind of income stood at $38 \%$ on average for the last decade but currently showing a decline trend (25\%during June 2019) due to slowdown in the performance of some sectors supporting such type of undertakings for e.g. Construction and export sectors. In addition, the significant growth of the banks' loan book also drives the interest income of banks on the high side. In addition to the gradual decline in the share of non-interest income from the total income of banks, their growth rate is also declining and stood lower than the growth rate of interest income. Despite such trend, however, the non-interest income sources remain a crucial part of the profit and loss account of the Ethiopian private banking system. Otherwise, the industry cannot be profitable by doing neither intermediation nor offering fee-based services alone. A mixed approach is a must to sustain the profitability of the banking sector. The decade long coverage of interest income to the total cost of banks is $102 \%$, with recent year figure shows some improvement but left little room for other non-operating costs like provisions and foreign exchange losses etc. Therefore, nurturing non-interest income sources will have paramount importance to sustain the growth and profitability of banks and even the recommended path should be diversifying of income sources via offering various service types. With such in mind, the impact of COVID 19 on non-interest income sources seems substantial considering pressures from various sources as indicated below:

\subsubsection{Pressure from Reduction of Charges and Commissions}

The historical industry framework was suitable for banks to generate a substantial income in their foreign trade service offerings as they do have a liberty to set charges of their own discretion. The liberty of charging basically emanates from the shortage in the availability of foreign currency and the high unmet demand of importers foreign currency demand. In other words, a Bank holding a reliable level of foreign currency obviously manages to easily convert its foreign assets to fee based income and associated gain from currency conversions. Additionally, a high demand in off balance sheet related services such as issuing guarantees and offering domestic banking services ensured another source of fee-based services increasing the income base of banks. The aforesaid services have contribution not only on the income base of banks but on the overall risk portfolios through directing their activities on almost risk-free services bearing a lower impact to affect their income positions. That is why banks were offering loans at a discount rate to the export sector. The pandemic however seriously is affecting not only the availability of the resources but also taken the liberty of banks to charge a free rider rate for the services. The recent request from the importers for reduction in L/C extension fees, borrowers for rescheduling fees, depositors for ATM fees and other charges can be cited as a good example of the lost liberty of price charges in the Ethiopian private banking system. Obviously, banks cannot indefinitely pursue such type of strategy as the intermediation activity alone cannot guarantee their profitability in the future. That will obviously will be clear during the beginning of the next fiscal year as the current situation is shadowed by the good performance record of banks in their nine-month profitability performances. Reversing the liberty of pricing can also not be a simple matter unless the exposed sectors revive well and is done in the short-term. Therefore, encouraging banks to diversify their activities towards fee-based income sources like advisory services for businesses and collecting fees from digital services must be a priority task to be done in the forthcoming. The direction of the NBE and the government in such regard supports such track.

7.2.2. Pressure from weak export performance (and other foreign currency earning sources) and guarantee business

As already stated in the previous sections, the expected decline in export and construction business will impact the foreign currency earning and guarantee exposure of banks. The combined effect will be to reduce the fee base income. Even if the impact is expected, the response from each private bank might not be the same. Therefore, supporting of small private banks that are highly reliant on fee-based income should deserve priority. Otherwise, 
those banks could be in a danger to sustainably perform in the industry.

Table 3: Share of Non-interest Income from the Total Income of Individual Private Banks

$\begin{array}{lllllllllll}\text { Bank } & 2010 & 2011 & 2012 & 2013 & 2014 & 2015 & 2016 & 2017 & 2018 & 2019 \\ 1 & 56 & 57 & 40 & 37 & 37 & 36 & 32 & 26 & 22 & 26 \\ 2 & 44 & 40 & 31 & 33 & 28 & 29 & 33 & 33 & 17 & 18 \\ 3 & 51 & 46 & 38 & 34 & 31 & 29 & 27 & 23 & 22 & 15 \\ 4 & 50 & 53 & 48 & 44 & 47 & 44 & 44 & 33 & 27 & 29 \\ 5 & 52 & 49 & 43 & 36 & 33 & 27 & 20 & 23 & 17 & 14 \\ 6 & 56 & 61 & 48 & 40 & 39 & 36 & 33 & 37 & 31 & 21 \\ \text { Tier 1- average } & \mathbf{5 2} & \mathbf{5 1} & \mathbf{4 1} & \mathbf{3 7} & \mathbf{3 6} & \mathbf{3 3} & \mathbf{3 2} & \mathbf{2 9} & \mathbf{2 3} & \mathbf{2 1} \\ 7 & 51 & 61 & 52 & 48 & 42 & 51 & 41 & 26 & 22 & 28 \\ 8 & 62 & 59 & 47 & 41 & 40 & 39 & 34 & 39 & 33 & 26 \\ 9 & 77 & 72 & 61 & 63 & 55 & 48 & 48 & 52 & 37 & 37 \\ 10 & 58 & 54 & 43 & 37 & 39 & 36 & 33 & 32 & 26 & 30 \\ 11 & 42 & 51 & 43 & 56 & 52 & 44 & 24 & 33 & 28 & 22 \\ 12 & 29 & 49 & 47 & 48 & 44 & 44 & 41 & 41 & 28 & 30 \\ \text { Tier 2 average } & \mathbf{5 3} & \mathbf{5 8} & \mathbf{4 9} & \mathbf{4 9} & \mathbf{4 5} & \mathbf{4 3} & \mathbf{3 7} & \mathbf{3 7} & \mathbf{2 9} & \mathbf{2 9} \\ 13 & & 60 & 56 & 48 & 44 & 43 & 34 & 37 & 34 & 40 \\ 14 & & & & 53 & 53 & 58 & 57 & 56 & 46 & 54 \\ 15 & & & & & 55 & 36 & 42 & 40 & 35 & 29 \\ 16 & & & & 66 & 62 & 58 & 54 & 49 & 47 & 41 \\ \text { Tier 3-average } & & \mathbf{6 0} & \mathbf{5 6} & \mathbf{5 6} & \mathbf{5 4} & \mathbf{4 9} & \mathbf{4 7} & \mathbf{4 6} & \mathbf{4 0} & \mathbf{4 1}\end{array}$

Further, analysis of fee-based dependence by banks shows that small private banks are more dependent on such income than the big private banks and the dependency reach up to $54 \%$ in some banks.

As shown above, the dependency level on non-interest income sources gradually declines depending on banks year of stay in the industry. This seems reasonable as it takes a realistic time to build a strong loan portfolio and maximize on the earning from interest income sources. The tier 1, tier 2 and tier 3 banks hold around $21 \%, 29 \%$ and $41 \%$ of their income from non-interest sources. Nevertheless, even with long year stay, there are some banks that are highly dependent on such income sources to ensure profitability. Even in most cases, Ethiopian private banks mostly will have a narrow profit margin or operate at loss if the noninterest income sources are highly affected by uncertain circumstances like COVID 19. This is because the majority (around 61\%) of their income is consumed by the cost of operations and other expenses. The talk of profitability arises with consideration of the non-interest income sources as almost $91 \%$ of the interest income is spent to cover expenses of the bank.

\subsection{Expenses}

With regard to cost of doing the banking business, the aggregate cost to income ratio of the private bank stood was $61 \%$ on average for the last decade. This has shown some a significant increase during the recent years (cost to income ratio was around $50 \%$ before 10 years but stood at $68 \%$ during 2019 ) due to substantial increases each component of expenses (interest, salary, rent and general expenses). Currently, private banks are expending 68 cents to generate 1 Birr income per their transactions. This signifies the fact that likewise revenue pressures, cost pressures could have significant impact to drain the profit of banks. Obviously, the next Management approach will have careful considerations on critical cost driven decisions like expansions through branch network and employment. Nevertheless, diverting more attention towards IT investments, e-banking channels, etc. Depending the length of stay of COVID 19, banks face a lot of pressure from each components of expenses as described below:

\subsubsection{Pressure from Interest Expense}

The share of interest expense of banks from the total expense stood around $40 \%$ on average for the last decade. However, recently, the percentage share has increased to $45 \%$ following the interest rate adjustment from the NBE on saving and time deposit (from 5\% to 7\%) and due to increase in share of time deposit in the deposit mix of private banks (from $7 \%$ to $12 \%$ ). Growth wise, the interest expense shows a parallel increment with the interest rate income of banks, which is around $33 \%$ on average. The cost of fund of the private banking system is around $4.75 \%$ (from $2.5 \%$ a decade before), which is lower as compared to the $7 \%$ minimum interest rate to be paid for saving and time deposit. This is due to the considerable share of zero cost demand deposit from the total deposit portfolio. Despite the change in the cost of fund of banks, the spread from the loan effective interest rate remained constant- around 9\% thanks to the liberalized lending market in Ethiopia. With the current situation however, it cannot be easy to alter the price of loans in consideration of the movement in the deposit rate/cost of fund as borrowers are expecting on lowering prices than otherwise. Therefore, policy decisions from the NBE shall not increase the minimum prices for saving and time deposit as such decisions could impact on the spread of banks. Otherwise, the pressure from cost of fund increase might not much felt unless there is a substantial price change from the lending activity of banks. 


\subsubsection{Pressure from reduced employee productivity and employee salary and benefits}

One of the severe consequences of the pandemic relates to its damaging impact on the unemployment level of a country. Unemployment rate is closely related to the well-functioning of the economy. According to Okun's law, for each percentage point of $1 \%$ above the natural unemployment rate, the economy could have produced potential output greater than $2.5 \%$ (Arthur Okun, 1962). This ratio allows us to calculate the absolute production loss associated with any unemployment rate. On the other hand, a fall in the unemployment rate leads to an increase in consumption and production (GDP), which also has a positive impact on GDP per capita. Several studies in Ethiopia also tried to estimate the impact of COVID on unemployment level and the studies confirmed that the pandemic could cause severe impact on job security. Nevertheless, the private banking sector is a stable employer having created job opportunities for more than 300 thousand employees. The sector has shown its resilience as firm employer via keeping its employees in a safe and caring environment and without consideration of layoffs. The average staff per branch is around 17 employees- of which the major part is covered by non-clerical staff (some of the banks have outsourced their security and janitorial services). As the level of activities are now limited across branches, staff are dedicated to office work as conducting marketing and campaigning works demand for physical contact, hence some banks are considering for a shift basis work schedule and reducing in the working hour (following the minimum working schedule 08.00 to 05:00 pm). In addition, banks are implementing systematic staff leave management so as to control the expenses from accumulated leave.

Even if the stable employer concept has been witnessed over the short-term, it might not sustain given the age of pandemic is long and profitability due to the factors mentioned in this document is affected. Therefore, the support to be provided to the banking sector has an implication to sustain the stable employer concept until the pandemic is under control.

\subsubsection{Pressure from Exchange Rate Variations}

Ethiopia follows a managed foreign exchange regime where the Ethiopian Birr is pegged against USD by policy and the currency rate with other currencies is freely determined based on the international market rate of other currencies with the USD. Banks are expected to get earnings from foreign exchange transaction through setting the difference between buying and selling exchange rate usually not exceeding $2 \%$. Even if the banks have the discretion to set the fees and commissions collected through offering international banking services, the currency gap is limited to $15 \%$ of capital by regulation. In order to insult themselves from foreign exchange rate valuation, banks follow strategy of holding major portion of their foreign asset in less volatile currencies like USD and limiting the exposure in unpredictable fluctuating currencies to the level used for transaction purpose. Generally, banks were in comfort zone with regard to exchange rate situation during the past years and the trend in exchange rate portrays a conscious policy measure that set down a gradual depreciation of Birr against USD. For instance, over 1990-2015, Birr has depreciated by 1.5 times against dollar i.e. from 7.98 to 20.096 within 25 years. But it took only five years for the Birr to depreciate by 1.7 (from 2015-2020) and depreciated by 20\% (1.1times) within 11 months of the fiscal year. Although such changes in exchange rate are a reflection of the government stance for a more liberalized and market determined exchange rate, it has a direct impact on performance of banks. With the current slowdown in foreign exchange earnings, it's obviously expected that banks maintain a short position/ currency gap in their currency position. Depreciation of local currency with short currency gap (more liability than asset holding) mean paying liabilities at a higher rate. This results in loss to the banks book as they are expected to settle their commitments at dear rate. Transaction related exchange rate differences are usually transferred to the customer; however, banks retain the exchange related loss related to their liability exposures (exposure on their retention account, non-resident accounts, diaspora accounts etc). Therefore, even if the exchange rate related measures are following the national strategies, banks foreign reserve positions should remain in reliable stand so as to contain exchange related losses. In such endeavor supporting banks through availing foreign exchanges and via lifting/relaxing foreign exchange surrender requirements is essential protection for the banking sector.

\subsubsection{Pressure from Inflation/Hyperinflation Situations}

With regard to inflation, the past year records show that inflation in Ethiopia has been low but the recent period records show that the economy has been operating with high inflationary spiral. It has been steadily soaring and creeping up in the recent period despite good harvest of agricultural produces. The general inflation exceeded $20 \%$ in recent year. From theoretical view point, a growing inflation rate is expected to affect performance of the economy making consumption expensive. This affects the saving rate in the economy and, hence, lowers the investment fund. This directly affects the growth in the economy and the financial system. From practical perspective, the Ethiopian banking system does not seem to feel the pressure from inflation due to its liberty to set the lending prices following the change in deposit rate that for long period ensures a constant spread. In addition, the variation in both lending and deposit rates was not frequent to disrupt banks' price setting mechanisms leading to almost a fixed rate regime in both asset and liability pricing. In the Ethiopian context, due to lifted inflation, the real saving rate has been negative in all periods considered. Similarly, the lending rate remained positive in most years of the period, but has been negative during the years with hyperinflation records- like the situation in the recent year. Studies however are not conclusive over the impact of inflation on bank performances. For 
instance, studies confirmed that the relationship between inflation and banks performance is debatable (Athanasoglo, 2005), the direction of relationship is unclear (Vong and Chan 2009) or the effect depends on whether inflation is anticipated or unanticipated (Perry 1992). However, banks operating under inflationary pressure obviously will be affected with the rise in the cost of their procurement engagements: increase in prices of materials (like stationaries, utilities etc), investment items, and fixed asset acquiring costs. In addition, fixed time depositors will have considerations on the movement of the inflation rate to set expectation on the acceptable level of interest rate. Regardless of the magnitude, the direction of an inflation pressure (which can exacerbate by the COVID impact) will be to increase the cost of doing banking business.

\subsubsection{Pressure from Increase in Rent Expense for Banking Branch Out}

The banking sector is one of the contributors for the flourishing of the real-estate sector in Ethiopia. Besides, the sectors high demand for branching and head office outlet, the banking sector was a reliable revenue source (banks are paying up to five years and more advance for rent) and financer of the real-estate sector. This has contributed for the timely completion of commercial buildings and ensured sustainable earning for the landlords. The high competition to secure a better located branch has also increased the office rent price allowing landlords to get a competitive price for their properties. The pandemic however, will have significant impact on the real-estate sector as lot of businesses are being closed/will be closed due to the travel ban and lockdown across the world. Although the sector will keep the already opened branches, it obviously revisits its new branching decisions as digital technologies are now a preferred way of banking services.

\section{Technology}

Technology is at the core of the banking business via ensuring productivity, innovativeness, fast transactions, realtime fund settlement etc. Technology makes banking smoother and seamless for the users. Ethiopian banks are criticized for the use and less adoption of technology. However, technological services are available like: debit cards, real time gross settlement, ATM's, core banking systems, National payment systems (clearing services),SWIFT, POS, mobile, internet, wallet banking etc. The main thing is to create awareness among the banking community regarding the available banking services. In addition, there is a lot to do in the technological front through introducing new and upgrading existing technologies. Offering e-cheques systems, National electronic fund transfers allowing funds transfer -mainly from any bank branch to any individual having an account with any other bank branch. The recent introduction of cash limit and national IT strategy also indicated the need for automation and calls out the need for digital path in the Ethiopian banking industry. Therefore, banks should pursue such path in their own, under consortium and with the support from the National Bank of Ethiopia.

\section{Physical Security and fraud}

The security of the financial sector is a number one priority list of the government. Recently, there were some robberies in few banks committed either at branch premises or while cash was in transit. For instance, fortune reported that '...... Many branches located in relatively secluded areas are becoming subject to armed robberies.' (Fortune, Feb 1,2020). Besides, fraud attempts involving both internal and external entities were reported in many of the banks. In times of such kind of crisis, financial institution are the primary targets of robbery and frauds. The worrying issue in such regard relates to lateness in the arrest of perpetrators, delayed investigation processes on fraud cases etc Therefore, the government through its concerned organs shall provide the required support in prevention of armed robberies via supporting them offering armaments, training security staff and providing special attention on bank frauds investigation and criminalization. Banks should also establish a well-founded security team, use technologies and enculturing the utmost required banking discipline to their staff and the management team.

\section{Measures Taken by the NBE- a comparison with central banks of East African nations}

Advanced economies are unveiling unprecedented economic stimulus packages. African countries, by contrast, lack the wherewithal to make similarly meaningful interventions. Yet if the virus is not defeated in Africa, it will only bounce back to the rest of the world. March 25,2020- Financial Times -Abiy Ahmed

Central banks of the East African Community member countries are contemplating swift interventions in response to the coronavirus crisis. The implications of the measures are similar and are intended to:

- mitigate the adverse impact of the COVID- 19 to the economy and more importantly to the financial sector;

- $\quad$ boost liquidity in the market as well as support commercial banks with cash that they could lend to various borrowers;

- $\quad$ provide incentives to banks to avoid increasing lending rates;

- Support commercial banks to provide relief to borrowers on their loans due to the Covid-19 pandemic;

- $\quad$ ensure liquidity in the market and keep businesses afloat during the difficult time of Covid-19 pandemic;

- Encourage the use digital channels and contactless mobile payments that sustain the payment of 
transactions even during the lockdown measures.

Table 4: Measures from East African Central Banks

\begin{tabular}{|c|c|c|c|}
\hline Bank of & $\begin{array}{l}\text { Keynya- CENTERAL } \\
\text { Bank of Kenya }\end{array}$ & $\begin{array}{l}\text { Tanzania- bank of } \\
\text { Tanzania }\end{array}$ & $\begin{array}{l}\text { Central } \\
\text { Rwanda }\end{array}$ \\
\hline $\begin{array}{l}\text { National Bank of } \\
\text { Ethiopia has availed 15- } \\
\text { billion-birr (About USD } \\
450 \text { million) liquidity for } \\
\text { private banks to enable } \\
\text { them to provide debt } \\
\text { relief and additional loans } \\
\text { to their customers in need } \\
\text { and especially the } \\
\text { businesses adversely } \\
\text { affected by COVID-19 } \\
\text { Extra funding for health } \\
\text { care facilities } \\
\text { Make foreign currency } \\
\text { available for imports of } \\
\text { products related to } \\
\text { curbing the coronavirus } \\
\text { outbreak the } \\
\text { Mobile transfer limits } \\
\text { have been increased } \\
\text { Removal of the } \\
\text { restriction on floor price } \\
\text { for flower exports that } \\
\text { was previously set by the } \\
\text { National Bank of } \\
\text { Ethiopia } \\
\text { Clamping down price } \\
\text { gouging by retailers to } \\
\text { protect low income } \\
\text { households a } \\
\text { Setting cash withdrawal } \\
\text { limits for natural and } \\
\text { judicial persons } \\
\text { Relaxing the } \\
\text { classification loan } \\
\text { provisioning directives } \\
\text { Allocating liquidity for } \\
\text { banks to channel credit to } \\
\text { vulnerable sectors- like } \\
\text { hotel and tourism and } \\
\text { flower export }\end{array}$ & $\begin{array}{l}\text { lowered the Central Bank } \\
\text { Rate (CBR) from } 8.25 \text { per } \\
\text { cent to } 7.25 \text { per cent, } \\
\text { reducing the Cash } \\
\text { Reserve Ratio (CRR) } \\
\text { from } 5.25 \text { per cent to } \\
4.25 \text { per cent, released } \\
\text { KES } 35.2 \text { billion as } \\
\text { additional liquidity } \\
\text { availed to banks to } \\
\text { directly support } \\
\text { borrowers that are } \\
\text { distressed as a result of } \\
\text { Covid-19 that the } \\
\text { decided the that } \\
\text { commercial banks will } \\
\text { now bear the cost } \\
\text { required to extend and } \\
\text { restructure loans during } \\
\text { the time of Covid-19 } \\
\text { pandemic and that banks } \\
\text { are to waive all charges } \\
\text { for balance inquiries. } \\
\text { zero charges for mobile } \\
\text { transactions of up to Kshs } \\
1,000 \text { increase } \\
\text { transaction limit to Kshs } \\
150,000 \text { (USD1447.7 } \\
30 \text { ); the mobile money } \\
\text { wallet limit and daily } \\
\text { transactions limit is } \\
\text { placed at Kshs } 300,000 \\
\text { (USD } 2895.46 \text { ). } \\
\text { The CBK has also } \\
\text { directed removal of the } \\
\text { monthly transactions } \\
\text { limit, and eliminating the } \\
\text { transfers between mobile } \\
\text { money wallets and bank } \\
\text { accounts. }\end{array}$ & $\begin{array}{l}\text { Control of high prices via } \\
\text { managing the exchange } \\
\text { rate } \\
\text { lowered the statutory } \\
\text { minimum reserves } \\
\text { requirement from } 7 \\
\text { percent to } 6 \text { percent with } \\
\text { effect from June } 8,2020 . \\
\text { reduction of the discount } \\
\text { rate from } 7 \text { percent to } 5 \\
\text { percent with effect from } \\
\text { May } 12 \text {, 2020, providing } \\
\text { an additional space for } \\
\text { banks to borrow from the } \\
\text { central bank at a lower } \\
\text { cost, thus signaling lower } \\
\text { lending rates by banks. } \\
\text { Mobile money operators } \\
\text { should increase daily } \\
\text { transaction limit to } \\
\text { customers from three } \\
\text { million Tanzanian } \\
\text { shillings (about } 1,296 \\
\text { U.S. dollars) to five } \\
\text { million shillings } \\
\text { financial institutions } \\
\text { should thoroughly assess } \\
\text { financial difficulties } \\
\text { experienced by } \\
\text { borrowers due to } \\
\text { COVID-19 in respect of } \\
\text { loan repayment and } \\
\text { discuss on the possibility } \\
\text { of restructuring of the } \\
\text { loans. }\end{array}$ & $\begin{array}{l}\text { It has brought into effect } \\
\text { the extension of lending } \\
\text { facilities } \\
\text { The BNR has put in place } \\
\text { a liquidity window to } \\
\text { allow the banks to } \\
\text { continue serving their } \\
\text { customers. } \\
\text { To facilitate the private } \\
\text { sector borrowers, a fund } \\
\text { close to } \$ 5 \text { million has } \\
\text { been earmarked to bridge } \\
\text { liquidity challenges and } \\
\text { commercial banks could } \\
\text { access the facility at the } \\
\text { central bank rate. } \\
\text { The Central Bank } \\
\text { announced lowering the } \\
\text { requirement ratio from } \\
\text { five per cent to four per } \\
\text { cent to allow banks more } \\
\text { liquidity to support } \\
\text { affected businesses. } \\
\text { Review of Treasury } \\
\text { Bonds has been done for } \\
\text { the next six months; BNR } \\
\text { has offered to buy back } \\
\text { bonds at the prevailing } \\
\text { market rate. } \\
\text { The regulator also } \\
\text { reduced the waiting } \\
\text { period if one fails to sell } \\
\text { the bond at the secondary } \\
\text { market from the current } \\
30 \text { days to } 15 \text { days. } \\
\text { banks are allowed to } \\
\text { engage their customers } \\
\text { and renegotiate terms } \\
\text { especially to those with } \\
\text { outstanding loans facing } \\
\text { temporary cash flow } \\
\text { challenges arising from } \\
\text { the pandemic }\end{array}$ \\
\hline
\end{tabular}

From the above analysis, the NBE is rightly responding to the crying need of the economy - announced a host of measures aimed at increasing liquidity in the economy. In addition, NBE need to consider policy tools to spur lending, amid fears that the COVID-19 pandemic will derail any revival of economic growth. The NBE has to:

- $\quad$ infuse fresh cash liquidity into the system, helping banks stance of maintaining satisfactory liquidity conditions;

- $\quad$ enable banks to secure cheaper funding via reducing the short-term lending at lower rate- which is now set at $13 \%$;

- a bit lower the statutory reserve requirement so as to increase the liquidity of banks

The steps taken in the recent past as regards to loan renegotiation, liquidity injection, cash limits, and other deserve high appreciation considering the ongoing global situation. 


\section{Bank's Involvement in COVID 19 Prevention and Control}

Besides the government step to contain the virus spread by putting in-place different measures banks were directly involved to fulfill their social responsibility. Banks taken the following action to respond to the government call:

- $\quad$ Director Grant to the National COVID-19 fund mobilization taskforce;

- Direct grant to regional fund mobilization committee;

- Reduce interest rate for vulnerable sectors like Horticulture, Hotel and Tourism sectors. As a result of the reduction of interest, they have forfeited significant amount of income;

- Banks are rescheduling loans of borrowers and are arranging for convenient terms of repayment. This is done free of charges.

- They are working to create awareness for its staff as well as customers about COVID-19 Pandemic. Similarly, they are availing the necessary protection materials for their staff allocating budget for such purpose;

- $\quad$ They are supporting the import of medical equipment via allocating foreign currency for COVID and Pharmaceutical related sectors ;

- Involved their staff in the initiative to mobilize fund to support the society;

\section{The Banking prospect after COVID}

From the economy side, sustainable economic growth will require societies to create conditions that allow people to have quality jobs that stimulate the economy while not harming the environment. Job opportunities and decent working conditions are also required for the whole working-age population. There needs to be increased access to financial services to manage incomes, accumulate assets, and make productive investments. Increased commitments to trade, banking, and agriculture infrastructure will also help increase productivity and reduce unemployment levels.

Industry wide, Industry concentration appears to be one of several factors affecting bank performances and the economy. For instance, Jeanneney and Kpodar (2005) finds that the weak relationship between finance and growth in Africa is partially due to concentration in the banking industries. The average Herfindahl-Hirschman Index (HHI) is as high as 2059, whilst the five-bank concentration ratio stands at $77.29 \%$ for the whole African region. On the positive side, concentration assumed a downward trend across all the sub regions over the past few years. Similarly, the banking structure of the Ethiopian banking industry demonstrate monopolistic competitive behavior. The industry concentration as measured by the Herfindahil Hirschamn Index (HHI) on average stood at 4830 and 3867 in the deposit and loan market, respectively. The level stood in a high concentration range. Trend wise, the HHI has been in the decline path specifically during the period 1999-2007 which has reduced from 7618 to 4326 and later (2008-2015) moved to the growth path due to the increased market share of the CBE (chart).

\section{Chart1: Market Structure}

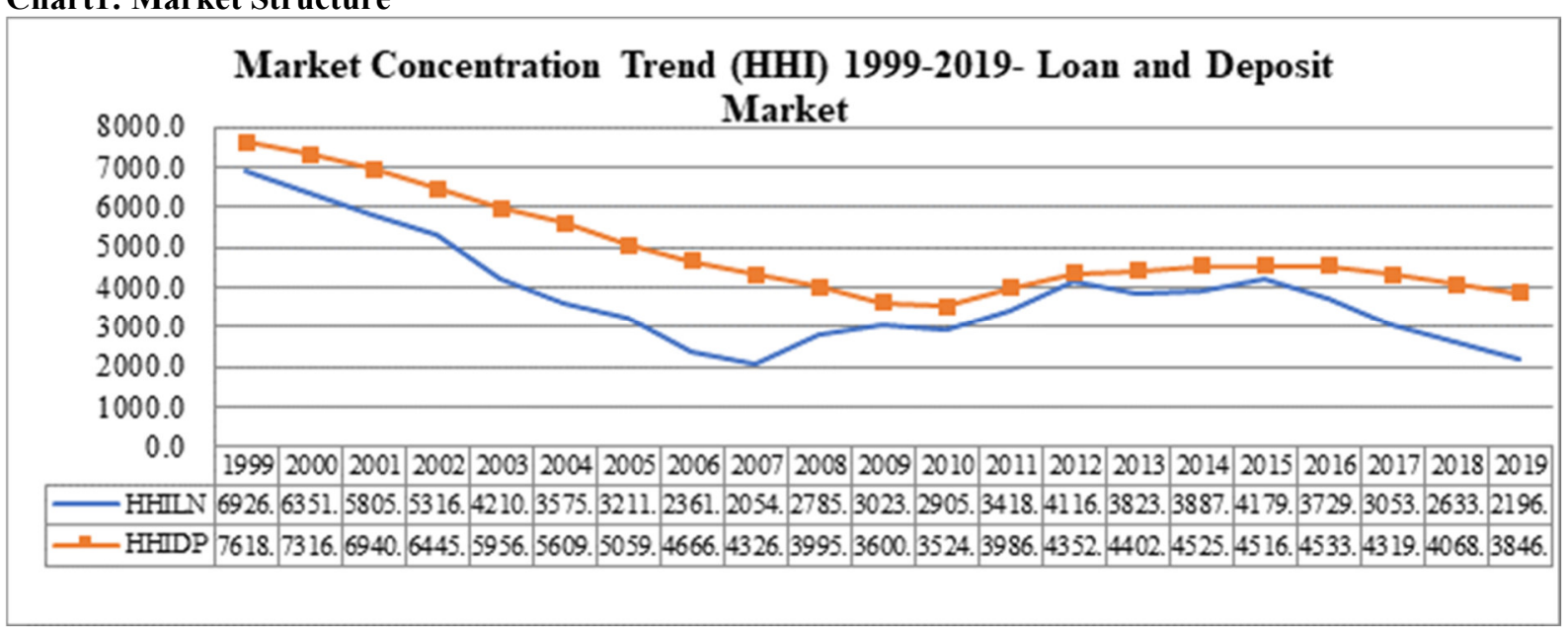

\section{Author's Computation}

The recent period (2016-2019) record shows a significant decrease in the market position of CBE in both markets. Despite noted fluctuations in the HHI measure the recent period records show that the dominance of the stateowned banks is not yet resolved. The contribution of recent entrants to the system has negligible effect to alter the market concentration towards diversifications. Therefore, in spite of the growth path trend in the private banking system, the market position of the big state-owned banks remains unaffected. Therefore, further reform measures to embark on financial sector restructuring involving deregulation, a relaxation of entry barriers to foreign investment, removing interest rate controls, limiting state ownership, developing securities markets, strengthening 
prudential regulation and supervision are some of the measures required in the Ethiopian banking sector. However, the entry of new local banks will take much time to reverse the current level of concentration, hence their effect in correcting the market structure or spur the competition level is insignificant. Therefore, market correction measures should focus on existing than new entrant banks- a comprehensive financial sector restructuring programs are needed to be established.

In terms of Digitalization, following the pace set by the new digital strategy of Ethiopia, banking business can be increased after Covid-19 with new sources of growth. Some of the traditional intermediation and fee-based services need a rethink and inevitably we have new drivers of growth like advisory services, e-commerce, digitalization, e-banking services etc. Online and digitalization will be the way forward. In addition, Banking services has to be intensified increasing credit flow to micro and small enterprises, marketing of products, technology up gradation and addressing issues in priority economy sectors like agriculture, service and industrial sectors.

\section{Summary and Conclusions}

The study tries to explore the historical progress in performance and reasons for success history of the banking sector by providing priority to the private banking system. In addition, the effect of the pandemic on the trends and the historical success factors was investigated. The result shows that:

- Resource Mobilization will not be an easy to do task considering the effect of the pandemic on the critical success factors: reduced per capital income, limited expansion in branch network and saving habit and bank usage. The slowdown in macroeconomic environment, banks' preference towards non-branch channels, limited personal selling and promotion tasks will impact on the level of local resource mobilization.

- Foreign currency mobilization from the two major sources like export and remittances will not follow the usual trend. Commodity price outlook for major export products was not positive. In addition, lockdowns, travel bans, loss of employment, return to home from middle east, Asia etc impacts the amount of remittances from the emigrants;

- The capital to asset ratio of banks was stable- around $14 \%$. However, due to the imminent high-risk exposure of banks arising from the pandemic, capital growth requirements should remain part of the regulatory precautions in the forthcoming.

- On the resource allocation front, credit growth is challenged by limited growth of resource mobilization, reduced credit demand from rational borrowers and restricted lending appetite of banks. Taking into account the degree of vulnerability of various sectors, it is estimated that the private banking system might not collect around Birr 40 billion and Birr 10 billion per annuum and per quarter, respectively from its loan portfolio stock due to aggressive rescheduling practices. This will impact the liquidity standing of banks in the future and alters the maturity profile of the banks' balance sheet.

- Prior to COVID 19, asset quality problems in the private banking system have no systemic nature and mostly was related to gaps in management of individual banks. Currently, however, an apparent pressure of default due to systemic problems are materialized and are being wisely dealt by the NBE via relaxing of asset classification and provisioning directives. Nevertheless, it demands strict monitoring to reduce its long-term repercussions.

- The negative impact of the pandemic on foreign currency mobilization apparently reduce the amount of import approval and the income generated from deploying foreign exchange resources (service fees plus revaluation gains). The impact is proportional to the magnitude of reduction in foreign currency earnings

- In terms of liquidity, the private banking system has reached the maximum limit on loanable funds (given 5 percent mandatory reserve requirement). Additional lending going forward will thus be more closely dependent on securing additional increases in deposits and will not be easily achieved as in the past year. Besides, slow in resource mobilization, the aggressive rescheduling on loans (intended to support borrowers by providing relaxed terms) alters the maturity profile of the banks' assets and liabilities via directing the loan portfolio towards medium and long term. The study estimates additional liquidity requirement for the private sector amounting Burr 17 billion is required to keep the $70 \%$ threshold or meet the NBE's $15 \%$ liquidity requirement by private banks. This is excluding the Birr 10 billion per quarter liquidity gap from delayed credit collection.

- The private banks are also extending supports via the off-balance sheet route. There has been an increase in the growth of off-balance sheet exposure in recent years and the role of private sector banks is improving on this score. The pandemic impact on the construction sector, on foreign exchange earning and liquidity determines the level of off-balance sheet and the earning thereof- which most of them remain a concern.

- Besides the balance sheet development, the last decade was also the time a strong performance in the 
earning of private banks was witnessed. However, key revenue sources will have a chance to be affected due to pressure from low demand, price reduction, accumulated low earning asset- mainly bill purchases, reduction of charges and commissions etc. Even if the impact is expected, the response from each private bank might not be the same. For instance, fee-based dependence by banks shows that small private banks are more dependent on such income sources than the relatively big private banks and the dependency reach up to $54 \%$ in some banks.

- On the cost side, a significant increase during the recent years (cost to income ratio was around $50 \%$ before 10 years but stood at $68 \%$ during 2019) due to substantial increases each component of expenses (interest, salary, rent and general expenses). Currently, private banks are expending 68 cents to generate 1 Birr income per their transactions. This signifies the fact that likewise revenue pressures, cost pressures could have significant impact to drain the profit of banks.

- With the current slowdown in foreign exchange earnings, it's obviously expected that banks maintain a short position/ currency gap in their currency position. Depreciation of local currency with short currency gap (more liability than asset holding) mean paying liabilities at a higher rate. Even if exchange rate related measures are following the national strategies, banks foreign reserve positions should remain in reliable stand so as to contain exchange related losses. In addition, regardless of the magnitude, the direction of an inflation pressure (which can be exacerbated by the COVID impact) will be to increase the cost of doing banking business.

- In times of such kind of crisis, financial institution are the primary targets of robbery and frauds. Lateness in the arrest of perpetrators, delayed investigation processes on fraud cases, etc are some of the concerns on the banks' physical security front.

- Ethiopian banks are criticized for the use and less adoption of technology. However, technological services are available like: debit cards, real time gross settlement, ATM's, core banking system, National payment systems (clearing services),SWIFT, POS, mobile, internet, wallet banking etc. The main thing is to create awareness among the banking community regarding the available banking services. In addition, there is a lot to do in the technological front through introducing new and upgrading existing technologies.

- The NBE is rightly responding to the crying need of the economy - announced a host of measures aimed at increasing liquidity in the economy. In addition, NBE need to consider policy tools to spur lending, amid fears that the COVID-19 pandemic will derail any revival of economic growth.

- As corporate citizen, banks are also positively responding to the request of the society through directly advancing funds to national and regional COVID committees, by providing reduction in interest rate, renegotiating loans, protecting staff, availing foreign currencies for COVID-19 related causes.

\section{Recommendations}

- On enhancing the resource base in addition to the banks management duty of instituting a creative way of approaching customers'-NBE need to consider:

- $\quad$ infuse fresh cash liquidity into the system, helping banks stance of maintaining satisfactory liquidity conditions- which is around Birr 17 billion. Banks will have a burden to cover liquidity of around Birr 10 billion per quarter due to delayed loan collections.

- $\quad$ enable banks to secure cheaper funding via reducing the short-term lending at lower rate- which is now set at $13 \%$.

- a bit lower the statutory reserve requirement/ allow certain portion of bill so as to increase banking resources. Beef up the capital reserve (setting a cap for dividend pay-out ratio).

- Similarly, Banks foreign reserve positions should remain in reliable stand so as to support the import demand and contain exchange related losses. In such endeavor:

- $\quad$ Lifting the surrender requirement for export related foreign currency earnings remains appropriate;

- Lifting the exchange commission payable to the NBE on each import transactions/currency approval which is $1.5 \%$ - should be looked at in order to allow banks further reduce their service charges on import approvals.

- Banks shall also be allowed to pay local commitments (like shipping and others) through home currency. Capital growth requirements should remain part of the regulatory precautions in the forthcoming. In such regard, the NBE should set enforcement measures to keep part of this and subsequent years profit to serve the buildup of the capital base of banks.

- The motive of creating a sustainable quality asset should not be compromised with the flexed new directives. Credit renegotiations measures should be comprehensive enough not to shelve problems and to enable resolve borrowers' debt repayment obligations. Workout strategies need to be seriously pursued in order to avoid long staying defaults. In addition, precautions with regard to: 
- $\quad$ Limiting the general provision expense for banks portfolio shall be limited not to be less than a certain threshold (not to be less than $3 \%$ of total loans as instance);

- Limiting the dividend payout ratio or fully retaining the current year profit as a cushion for credit risk;

- In-placing close monitoring on restructured loans and subsequent reporting on their progress to the NBE. With regard to guarantee services banks should work jointly with the government:

- Contractors screening procedures should be tighter than the usual way during project awarding decisions;

- Project execution milestones should be seriously monitored so that claims to the banking sector shall be avoided or minimized; and

- Most importantly contractors failing to deliver their contracts shall be severely dealt with so as to avoid future contract failures and project delays.

- For new credit extension request from identified vulnerable sectors, the response from the NBE was positive and timely as it decided to offer liquidity to banks at reduced rate so that they can lend it at $5 \%$ interest rate. However, in order to support the banks further measures are necessary such as:

- To exempt banks from holding provision on such loans as they don't have commercial motives (at minimum banks are expect to hold $1 \%$ provision for their new credit exposures having a pass status, the provision rate increase whenever the credit status changes)

- Provide guarantee to banks in case of default so that the risk shall be transferred from banks to the government;

- Increase the interest rate to reasonable level so as to broaden the interest rate spread and to at least cover the cost of credit of banks.

- Most importantly, the liberty of banks to set lending price should not be compromised even during at this time as the banks' income base is very sensitive and prone to reduction to interest rate.

- The NBE response on long staying bill purchase requirement is also appreciable considering: 1 . The total lifting of bill purchase requirements 2 . An increase in the new bill prices from 3 to $5 \%$. 3. Permitting part of the bill for liquidity purpose before the maturity date (a year and wo months ahead). At this critical point the NBE should enhance its support to the private banking system via:

- Revisiting the price of bills (old and new) in a way at least to cover the minimum saving rate of banks plus a margin for credit related costs;

- Allowing banks to utilize a certain portion of the bill during stressful liquidity situation without charging interest;

- Most importantly, refraining from issuing similar directives associated to bank resources regardless of the causes. Geda (2020) recommended the NBE to introduce COVID bond in consultation with the banking community with the ultimate objective of mobilizing fund for the prevention and control of the pandemic. Nevertheless, this remains to repeat the previous history and shortcomings of the bill purchase directives of the NBE.

- Selectively supporting small private banks that are highly reliant on fee-based income should deserve priority. Otherwise, those banks could be in a danger to sustainably perform in the industry. Encouraging banks to diversify their activities towards fee-based income sources like advisory services for businesses and collecting fees from digital services must be a priority task to be done in the forthcoming. The direction of the NBE and the government in such regard supports such track.

- The recent introduction of cash limit and national IT strategy also indicated the need for automation and calls out the need for digital path in the Ethiopian banking industry. Therefore, banks should pursue such path in their own, under consortium and with the support from the National Bank of Ethiopia.

- The government through its concerned organs shall provide the required support in prevention of armed robberies via supporting them offering armaments, training security staff and providing special attention on bank frauds investigation and criminalization. Banks should also establish a well-founded security team, use technologies and enculturing the utmost required banking discipline to their staff and the management team.

- Further reform measures to embark on financial sector restructuring involving deregulation, a relaxation of entry barriers to foreign investment, removing interest rate controls, limiting state ownership, developing securities markets, strengthening prudential regulation and supervision are some of the measures required in the Ethiopian banking sector. However, the entry of new local banks will take much time to reverse the current level of concentration, hence their effect in correcting the market structure or spur the competition level is insignificant. Therefore, market correction measures should focus on existing than new entrant banks.

- A comprehensive financial sector restructuring programs are needed in order to speed up the recovery process after COVID and intensify banking services via increasing credit flow to micro and small enterprises, marketing of products, technology up gradation and addressing issues in priority economy sectors like agriculture, service and industrial sectors. 


\section{References}

Abel, M.(2016). The Relationship between National Saving and Economic Growth in Ethiopia: ARDL and Granger causality Approaches: Addis Ababa University.

Abiy Ahmed (2020). If Covid-19 is not beaten in Africa it will return to haunt us all; Financial Times -March 25,2020. https://www.ft.com/content/c12a09c8-6db6-11ea-89df-41bea055720b- accessed on June 1,2020.

Allen, F. and Carletti, E. (2008), "Mark-to-Market Accounting and Liquidity Pricing," forthcoming, Journal of Accounting and Economics, finance. wharton.upenn.edu/\%7Eallenf/download/Vita/Allen-Carletti-MMA200706- final.pdf).

Bendixen and Amandi (B\&A) (2010) Future of African Remittances: National Surveys Ethiopia, 2010

Berger, A. and Humphrey, D. (1991). Bank scale economies, mergers, concentration, and efficiency: The US experience. Working Paper 94-25, Financial Institutions Centre, The Wharton School, University of Pennsylvania.

Cepheus Research ( 2020). Macroeconomic Impacts of the Corona Virus: A Preliminary Assessment for Ethiopia: https://cepheuscapital.com/wp-content/uploads/2019/01/Macroeconomic-Impacts-of-the-Corona-Virus-APreliminary-Assessment-for-Ethiopia-r1.pdf accessed on June 1,2020

Dang, U. ( 2011) The CAMEL Rating System in Banking Supervision: a Case Study of Arcada University of Applied Sciences, International Business.

Demirguc-Kunt, A. and Huizinga, H. (1999). Determinants of commercial bank interest margin and profitability: some international evidence, World Bank Economic Review, Vol. 13(2), pp. 379-408.

EEA (2020). Economic and welfare effects of COVID-19 and Responses in Ethiopia: Initial insights:https://www.eeaecon.org/sites/default/files/publications/Economic\%20Impacts\%20of\%20Coronavi rus\%20and\%20\%20Responses\%20in\%20Ethiopia_08042020.pdf. accessed on June 2020.

Fortune new

paper,

Bank Robbery Rampant as Police Fail to Arrest Perpetrators (February 1, 2020)

Geda, A. (2020). The Macroeconomic and Social Impact of COVID-19 in Ethiopia and Suggested Directions for Policy Response, Addis Ababa University,

Growth and Trnasformation Plan of Ethiopia I and II

IMF Country Report No. 20/150 The Federal Democratic Republic of Ethiopia World Bank,2020

Isik, I. and Hassan, M. (2002). Technical, scale and allocative efficiencies of Turkish banking industry, Journal of Banking and Finance, Vol. 26 No. 4, pp. 719-66.

Jeanneney, S and Kpodar, K., (2005). Financial development, financial instability and poverty. CSAE WPS/200509, University of Auvergne, Auvergne.

Jember, Y (2016) The Relationship Between Gross Domestic Savings And Economic Growth In Ethiopia, Addis Ababa University.

Lelissa, T.(2014), Efficiency of Ethiopian Banks: the Data Envelopment Analysis, European Journal of Business and Management, pp.30-36.

Liu, H., \& Wilson, J. (2010). The profitability of banks in Japan. Applied Financial Economics, 20, pp.1851-1866.

Mishkin, F. S. (2001) The Economics of Money, Banking and Financial Markets, 6th edn, London: Addison Wesley. Money and banking Proclamation No. 83/1994

Nachane, D. and Ghosh, S. (2007). An Empirical Analysis of the Off-Balance Sheet Activities of Indian Banks, Journal of Emerging Market Finance, 6, PP. 39-45.

National Bank Reports of various editions

Okun, Arthur M. (1962). Potential GNP: Its Measurement and Significance, Proceedings of the Business and Economics Statistics Section of the American Statistical Association.

Rose, P. and Hudgins, S. (2008). Bank Management and Financial Services, 8e, McGrawHill/Irwin.

Samuel, E. and Abebe ,W.(2015) . Casual Relationship Between Gross Domestic Saving And Economic Growth In East Africa: Evidence From Ethiopia, Uganda And Kenya; Journal of Agriculture and Social Research, Vol. 15, No. 2.

The World Bank 2019 data update Remittance and Emigration. https://www.worldbank.org/en/topic/labormarkets/brief/migration-and-remittances. Accesed on June 2020

Various directives of the NBE: Directives SBB/53/12;Directives SBB27/01; Directives BSD09/2015; Directives SBB 43/2008; Directives SBB 55/2013

Websites of Central Bank of Kenya, bank of Tanzania and Central Bank of Rwanda

World Bank(2017). The Global Findex Database 2017: Measuring Financial Inclusion and the Fintech Revolution 


\section{Annex 1- Growth Rates}

Growth rate

Total Assets

Loans \& Advances

Total Deposits

Time Deposits

Saving Deposit

Demand Deposits

Total Capital \& Reserve

Provision for doubtful loans

Net Loans \&Advances

Total Income

Interest Income

Non-Interest Income

Total Expense

Interest Expense

Non-Interest Expenses

Net interest income

Profit Before Tax

Profit after tax

No. of Branches

No. of Staff

$\begin{array}{rrrrrrrrrrr}2010 & 2011 & 2012 & 2013 & 2014 & 2015 & 2016 & 2017 & 2018 & 2019 & \text { Average } \\ 14.2 & 27.5 & 20.8 & 29.4 & 21.4 & 21.8 & 27.1 & 36.4 & 34.0 & 29.9 & 26.2 \\ 7.2 & 22.1 & 34.1 & 28.0 & 19.8 & 40.9 & 23.1 & 44.5 & 34.6 & 41.1 & 29.5 \\ 16.0 & 30.5 & 18.5 & 29.3 & 20.3 & 27.1 & 24.1 & 36.5 & 35.4 & 29.9 & 26.8 \\ 5.5 & -10.5 & 77.7 & 28.6 & 41.6 & 48.4 & 37.1 & 51.2 & 35.8 & 28.4 & 34.4 \\ 23.5 & 22.1 & 22.9 & 29.7 & 20.1 & 26.1 & 21.4 & 36.3 & 36.7 & 33.0 & 27.2 \\ 13.0 & 40.5 & 16.8 & 28.3 & 15.9 & 23.5 & 25.6 & 31.8 & 32.5 & 23.7 & 25.2 \\ 9.5 & 35.3 & 29.7 & 22.3 & 30.9 & 20.0 & 20.8 & 35.9 & 26.2 & 32.4 & 26.3 \\ -11.5 & -6.6 & 2.0 & 27.1 & 6.2 & 22.7 & 25.8 & 43.1 & -4.4 & 899.0 & 100.3 \\ 8.1 & 23.3 & 35.1 & 28.0 & 20.1 & 41.2 & 22.9 & 44.7 & 35.3 & 30.3 & 28.9 \\ 15.2 & 37.8 & 26.6 & 23.1 & 28.4 & 28.5 & 24.0 & 34.1 & 40.7 & 33.2 & 29.2 \\ -6.6 & 34.9 & 52.3 & 28.8 & 30.6 & 33.3 & 31.2 & 38.5 & 53.9 & 34.4 & 33.1 \\ 46.3 & 40.4 & 4.2 & 15.8 & 25.3 & 21.5 & 12.3 & 25.8 & 13.2 & 29.7 & 23.4 \\ 6.4 & 36.5 & 30.4 & 36.7 & 31.9 & 38.6 & 32.2 & 35.0 & 43.1 & 29.7 & 32.1 \\ 5.9 & 39.3 & 36.2 & 26.0 & 28.2 & 32.1 & 32.1 & 32.4 & 64.3 & 41.3 & 33.8 \\ 6.8 & 34.5 & 26.3 & 45.0 & 34.4 & 42.9 & 32.4 & 36.6 & 30.9 & 21.3 & 31.1 \\ -14.5 & 31.3 & 65.6 & 30.7 & 32.2 & 34.0 & 30.7 & 42.3 & 47.8 & 29.8 & 33.0 \\ 25.5 & 41.9 & 22.7 & 8.2 & 23.6 & 13.5 & 9.2 & 32.0 & 35.6 & 41.3 & 25.3 \\ 25.3 & 42.7 & 26.4 & 10.7 & 23.9 & 13.0 & 11.5 & 29.7 & 39.4 & -100.0 & 12.3 \\ 0.7 & 11.5 & 42.0 & 29.7 & 36.6 & 33.3 & 31.2 & 32.4 & 18.6 & 17.8 & 25.4 \\ 0.4 & 0.7 & 35.7 & 36.4 & 20.0 & 18.5 & 18.0 & 19.7 & 19.1 & 18.6 & 18.7\end{array}$

\section{Annex 2: Key Ratios}

Ratios
Capital to asset
Capital to loan
Asset growth
Loan growth
Capital growth
Loan to deposit
Provision to loans
Loan Growth
Loan to total asset
Loan to deposit
Loans and bills to deposit
Provision to loans
Bills to loans
Deposit Growth
Interest income to total income
Non- interest income to total income
Net interest income to total income
Cost to income
Non interest income to operating income
Interest expense to total expense
Non-interest expense to total expense
Interest expense to interest income
Non-interest expense to non-interest income
Non-interest expense to interest income
Total expense to interest income
Total expense to non-Interest income
Cost of fund
Effective interest rate on loans
Spread
Staff per branch

$\begin{array}{rrrrrrrrrrr}2010 & 2011 & 2012 & 2013 & 2014 & 2015 & 2016 & 2017 & 2018 & 2019 & \text { Average } \\ 12.5 & 13.2 & 14.2 & 13.4 & 14.5 & 14.3 & 13.6 & 13.5 & 12.7 & 13.0 & 13.5 \\ 29.7 & 32.9 & 31.8 & 30.4 & 33.2 & 28.3 & 27.8 & 26.1 & 24.5 & 23.0 & 28.8 \\ 14.2 & 27.5 & 20.8 & 29.4 & 21.4 & 21.8 & 27.1 & 36.4 & 34.0 & 29.9 & 26.2 \\ 7.2 & 22.1 & 34.1 & 28.0 & 19.8 & 40.9 & 23.1 & 44.5 & 34.6 & 41.1 & 29.5 \\ 9.5 & 35.3 & 29.7 & 22.3 & 30.9 & 20.0 & 20.8 & 35.9 & 26.2 & 32.4 & 26.3 \\ 56.1 & 52.5 & 59.4 & 58.8 & 58.5 & 64.8 & 64.3 & 68.1 & 67.7 & 73.5 & 62.4 \\ 4.8 & 4.1 & 3.8 & 4.1 & 3.7 & 3.7 & 3.9 & 3.9 & 3.5 & 3.2 & 3.5 \\ 7.2 & 22.1 & 34.1 & 28.0 & 19.8 & 40.9 & 23.1 & 44.5 & 34.6 & 41.1 & 29.5 \\ 42.0 & 40.2 & 44.7 & 44.2 & 43.6 & 50.4 & 48.9 & 51.8 & 52.0 & 56.5 & 47.4 \\ 56.1 & 52.5 & 59.4 & 58.8 & 58.5 & 64.8 & 64.3 & 68.1 & 67.7 & 73.5 & 62.4 \\ 60.9 & 69.5 & 83.9 & 84.7 & 83.0 & 92.7 & 92.7 & 95.0 & 94.0 & 102.2 & 85.8 \\ 4.8 & 4.1 & 3.8 & 4.1 & 3.7 & 3.7 & 3.9 & 3.9 & 3.5 & 2019.0 & 205.4 \\ 8.6 & 32.4 & 41.2 & 44.0 & 41.9 & 42.9 & 44.1 & 39.5 & 38.9 & 39.0 & 37.3 \\ 16.0 & 30.5 & 18.5 & 29.3 & 20.3 & 27.1 & 24.1 & 36.5 & 35.4 & 29.9 & 26.8 \\ 47.7 & 46.7 & 56.1 & 58.7 & 59.7 & 61.9 & 65.5 & 67.6 & 74.0 & 74.6 & 61.2 \\ 52.3 & 53.3 & 43.9 & 41.3 & 40.3 & 38.1 & 34.5 & 32.4 & 26.0 & 25.4 & 38.8 \\ 26.7 & 25.4 & 33.3 & 35.3 & 36.4 & 37.9 & 40.0 & 42.4 & 44.6 & 43.4 & 36.5 \\ 51.2 & 50.8 & 52.3 & 58.1 & 59.6 & 64.3 & 68.6 & 69.1 & 70.2 & 68.4 & 61.3 \\ 66.2 & 67.7 & 56.9 & 53.9 & 52.6 & 50.1 & 46.3 & 43.3 & 36.9 & 36.9 & 51.1 \\ 40.9 & 41.8 & 43.7 & 40.2 & 39.1 & 37.3 & 37.2 & 36.5 & 41.9 & 45.7 & 40.4 \\ 59.1 & 58.2 & 56.3 & 59.8 & 60.9 & 62.7 & 62.8 & 63.5 & 58.1 & 54.3 & 59.6 \\ 44.0 & 45.5 & 40.7 & 39.8 & 39.1 & 38.7 & 39.0 & 37.3 & 39.8 & 41.8 & 40.6 \\ 57.8 & 55.4 & 67.1 & 84.0 & 90.1 & 106.0 & 124.9 & 135.6 & 156.8 & 146.6 & 102.4 \\ 63.5 & 63.3 & 52.5 & 59.1 & 60.8 & 65.2 & 65.8 & 64.9 & 55.2 & 49.8 & 60.0 \\ 107.5 & 108.8 & 93.2 & 98.9 & 99.9 & 103.9 & 104.7 & 102.2 & 94.9 & 91.6 & 100.6 \\ 97.9 & 95.2 & 119.1 & 140.6 & 148.0 & 168.9 & 198.9 & 213.5 & 269.9 & 269.8 & 172.2 \\ 2.5 & 2.8 & 3.1 & 3.1 & 3.2 & 3.5 & 3.6 & 3.7 & 4.4 & 4.8 & 3.5 \\ 9.4 & 10.4 & 11.8 & 11.9 & 13.0 & 12.3 & 13.1 & 12.6 & 14.4 & 13.7 & 12.3 \\ 6.9 & 7.6 & 8.7 & 8.8 & 9.7 & 8.8 & 9.5 & 8.9 & 9.9 & 8.9 & 8.8 \\ 34.2 & 7.8 & 25.2 & 26.5 & 23.3 & 20.7 & 18.6 & 16.8 & 16.9 & 17.0 & 20.7\end{array}$




\section{Annex 3: Deposit Mix}

\begin{tabular}{llllll} 
& & & \multicolumn{4}{c}{ Deposit amount Millions of Birr } \\
& Total & \multicolumn{1}{c}{ Time } & \multicolumn{1}{c}{ Saving } & \multicolumn{1}{c}{ Demand } & \multicolumn{1}{c}{ Time } \\
Deposits & Deposits & \multicolumn{1}{c}{ Deposit } & Deposits & Deposits \\
2010 & 38,132 & 2,585 & 24,372 & 11,176 & 7 \\
2011 & 49,754 & 2,313 & 29,761 & 15,698 & 5 \\
2012 & 58,979 & 4,112 & 36,579 & 18,339 & 7 \\
2013 & 76,261 & 5,287 & 47,441 & 23,534 & 7 \\
2014 & 91,752 & 7,487 & 56,998 & 27,267 & 8 \\
2015 & 116,655 & 11,110 & 71,864 & 33,681 & 10 \\
2016 & 144,763 & 15,226 & 87,231 & 42,306 & 11 \\
2017 & 197,628 & 23,016 & 118,868 & 55,743 & 12 \\
2018 & 267,593 & 31,255 & 162,453 & 73,885 & 12 \\
2019 & 347,618 & 40,125 & 216,100 & 91,393 & 12
\end{tabular}

\begin{tabular}{|c|c|c|c|c|c|}
\hline \multicolumn{3}{|c|}{ \%ge share } & \multicolumn{3}{|c|}{ Growth in \% } \\
\hline Saving & Demand & Total & Time & Saving & Demand \\
\hline Deposit & Deposits & Deposits & Deposits & Deposit & Deposits \\
\hline 64 & 29 & 16 & 6 & 23 & 13 \\
\hline 60 & 32 & 30 & -11 & 22 & 40 \\
\hline 62 & 31 & 19 & 78 & 23 & 17 \\
\hline 62 & 31 & 29 & 29 & 30 & 28 \\
\hline 62 & 30 & 20 & 42 & 20 & 16 \\
\hline 62 & 29 & 27 & 48 & 26 & 24 \\
\hline 60 & 29 & 24 & 37 & 21 & 26 \\
\hline 60 & 28 & 37 & 51 & 36 & 32 \\
\hline 61 & 28 & 35 & 36 & 37 & 33 \\
\hline 62 & 26 & 30 & 28 & 33 & 24 \\
\hline
\end{tabular}

Annex 4: Remittance Inlow

Migrant remittance inflows

2015

2016

2017

2018

2019e

Remittances

as a share of

GDP in

$2019(\%)$

\section{Low-and Middle-Income Countries World}

Sub-Saharan Africa

Ethiopia

$\begin{array}{rr}\mathbf{4 5 3 , 0 4 1} & \mathbf{4 4 6 , 2 5 1} \\ \mathbf{6 0 2 , 8 4 9} & \mathbf{5 9 7 , 3 3 2} \\ 36 & 38 \\ 1,087 & 772\end{array}$

$\begin{array}{rrr}\mathbf{4 8 6 , 6 8 9} & \mathbf{5 3 0 , 6 5 0} & \mathbf{5 5 4 , 2 1 8} \\ \mathbf{6 4 3 , 2 7 0} & \mathbf{6 9 4 , 4 7 9} & \mathbf{7 1 4 , 2 4 9} \\ 42 & 47 & 49 \\ 393 & 436 & 531\end{array}$

Source: World Bank

Annex 5 : Loan Portfolio Distribution

\begin{tabular}{|c|c|c|c|c|c|c|c|c|c|}
\hline \multirow[b]{2}{*}{ Borrowing Sector } & \multicolumn{3}{|c|}{ Public banks (1) } & \multicolumn{3}{|c|}{ Private banks (2) } & \multicolumn{3}{|c|}{ Total $3=1+2$} \\
\hline & D & $\mathrm{C}$ & OS & $\mathrm{D}$ & $\mathrm{C}$ & OS & $\mathrm{D}$ & $\mathrm{C}$ & OS \\
\hline Agriculture & 5,631 & 11,105 & 18,470 & 182 & 226 & 1,918 & 5,813 & 11,330 & 20,388 \\
\hline Industry & 11,923 & 8,595 & 150,718 & 4,726 & 3,469 & 37,959 & 16,648 & 12,064 & 188,677 \\
\hline Domestic Trade & 578 & 429 & 5,639 & 7,237 & 6,498 & 59,767 & 7,815 & 6,927 & 65,406 \\
\hline International Trade & 796 & 610 & 19,852 & 8,059 & 7,302 & 82,383 & 8,855 & 7,912 & 102,235 \\
\hline Export & 331 & 212 & 9,212 & 5,241 & 5,221 & 56,916 & 5,573 & 5,433 & 66,128 \\
\hline Import & 465 & 399 & 10,640 & 2,817 & 2,081 & 25,467 & 3,282 & 2,479 & 36,107 \\
\hline Hotels and Tourism & 311 & 314 & 4,964 & 1,270 & 912 & 8,777 & 1,581 & 1,225 & 13,741 \\
\hline Transport and Communication & 18 & 143 & 1,020 & 487 & 1,532 & 11,335 & 506 & 1,675 & 12,355 \\
\hline Housing and Construction & 1,038 & 486 & 12,850 & 4,629 & 2,876 & 38,459 & 5,666 & 3,362 & 51,309 \\
\hline Mines, Power and Water Res & 297 & 134 & 1,514 & 1 & 13 & 118 & 298 & 147 & 1,632 \\
\hline Others & 768 & 233 & 3,979 & 438 & 330 & 1,928 & 1,206 & 563 & 5,907 \\
\hline Personal & 1,047 & 1,257 & 25,458 & 1,909 & 898 & 15,296 & 2,956 & 2,154 & 40,754 \\
\hline Central Government & & & 54,238 & & & & & & 54,238 \\
\hline & 22,407 & 23,307 & 298,702 & 28,937 & 24,056 & 257,940 & 51,344 & 47,359 & 556,642 \\
\hline
\end{tabular}


Annex 6: Off balance sheet

In millions of Birr

2015

2016

2017

2018

2019

Guarantees Issued Local \& Foreign

$11,681.38$

$16,128.62$

$20,962.16$

$32,977.74$

$45,452.43$

\%growth

58.4

38.1

30.0

57.3

37.8

Banks liability on $\mathrm{L} / \mathrm{C}$

$7,267.52$

$10,107.15$

$14,713.86$

$13,683.29$

$15,369.94$

\%growth

(7.7)

39.1

45.6

(7.0)

usd liability- LC

\section{Annex 7- Effect of Interest rate reduction}

Loan Balance

Hotel and Tourism

8,777

Flower export

1,322

Total

Reduction in interest rate on average

7 percentage point

3 percentage point

Lost interest income three months

153.6

10

163.6 